\title{
Semi-direct speech: Manambu and beyond
}

\author{
Alexandra Y. Aikhenvald * \\ Research Centre for Linguistic Typology, La Trobe University, Melbourne, Vic 3084, Australia
}

Received 10 April 2007; received in revised form 29 June 2007; accepted 12 July 2007

\begin{abstract}
Every language has some way of reporting what someone else has said. To express what Jakobson [Jakobson, R., 1990. Shifters, categories, and the Russian verb. Selected writings. Word and Language. Mouton, The Hague, Paris, pp. 130-153] called 'speech within speech', the speaker can use their own words, recasting the original text as their own, within an 'indirect' speech construction. Or the other person may be quoted 'directly', just as they said it, or more or less so. One major difference between direct and indirect speech lies in the way person specification within the speech report is cast. In direct speech, person reference is expressed exactly as it was in the original speech report. In indirect speech, the person reference is shifted to the perspective of the speaker. There is a third option - a 'middle ground' situation known as 'semi-direct' speech - with incomplete person shift. Semi-direct speech often involves coreferentiality between the current speaker - rather than the author of the speech report - and a participant within the speech report. In Manambu, a Ndu language spoken in the New Guinea area, semi-direct speech differs from both direct and indirect speech in a few interesting ways. Further examples of semi-direct speech and its various guises come
\end{abstract}

Abbreviations: A, subject of transitive verb; ACC, accusative; ACT.FOC, action focus; ADVS, adverbializer; AUX, auxiliary; BAS.NP, basic nonpast cross-referencing; CAUS, causative; COM, comitative; COMPL, completive aspect; COMPL:SS, completed action same subject; CONF, confirmation marker; COP, copula; CS, Current Speaker; DAT, dative; DAT.SG, dative singular; DECL, declarative; DEM.DIST, distal demonstrative; DES, desiderative; DIR.SP.REP, direct speech report; du, dual; excl, exclusive; fem, feminine; FUT, future; IMPV, imperative; INCL, inclusive; IND.SP.REP, indirect speech report; IPTV, imperfective; LK, linker; LOC, locative; LOG, logophoric; masc, masculine; NEG, negative; NOM.PL, nominative plural; NP, nonpast; NR, nominalizer; O, object of a transitive verb; OBJ, object marker; OBL, oblique; OS, Original Speaker; P, past; pers, person; PERF, perfective; PERM, permissive; pl, PL, plural; POSS, possessive; PRO, pronoun; PROG, progressive; PURP.DS, purposive different subject; PURP.SS, purposive same subject; QUOT, quotative; RED, reduplication; RP, reported speech marker; S, subject of intransitive verb; SEQ, sequential; sg, singular; SS, same subject; SUB, subordinative; SUBJ, subject cross-referencing set; VOC, vocative.

* Tel.: +61 3 94796402; fax: +61394673053.

E-mail address: a.aikhenvald@latrobe.edu.au 
from a number of African languages, other languages from New Guinea area, and Colloquial English. The existence of a semi-direct speech construction brings an additional dimension to the typology of speech reports: the necessity of including the perspective of current speaker in the overall picture.

(C) 2007 Elsevier Ltd. All rights reserved.

Keywords: Direct and indirect speech; Semi-direct speech; Papuan languages

\section{The problem: speech reports with incomplete person shift}

\subsection{Direct and indirect speech reports}

Every language has some way of reporting what someone has said. To express what Jakobson (1990, p. 130) called 'speech within speech', the speaker can use their own words, recasting the original text as their own, within an 'indirect' speech construction. Or the other person can be quoted 'directly', just as they said it, or more or less so. In some languages, such 'direct' speech is the only type of speech report. Others have an array of structures on a continuum between 'direct' quotation and 'indirect' speech. One major difference between direct and indirect speech lies in the person of participants within the speech report.

In a direct speech construction, the speech report content corresponds exactly (or more or less so), to what the 'Original Speaker', that is, the author of the speech report content, had said. Consider the English sentences (1a) and (1b):

(1a) John ${ }_{i}$ said: 'I $I_{i}$ saw Fred yesterday'

(1b) John said: 'He $_{\mathrm{j}}$ saw Fred yesterday'

In both examples, the direct speech report - marked with quotes in the written language is postposed to the reporting verb 'say'. There is no overt link between the two. In (1a), the personal pronoun 'I' is coreferential with the Original Speaker, 'John', and is used within the speech report. In (1b), the personal pronoun 'he' is not coreferential with the Original Speaker. The subject of the speech report is someone other than John.

Alternatively, the report may be made without using his or her exact words, cast as 'indirect speech'. Then the person reference within a speech report is adapted to the perspective of the Current Speaker. In (2a), the original 'I' (used by John in (1a)) is changed to 'he':

(2a) $\mathrm{John}_{\mathrm{i}}$ said (that) he $\mathrm{i}_{\mathrm{i}}$ had seen Fred the previous day

And in (2b) 'he' used by John in (1b) is preserved

$$
\mathrm{John}_{\mathrm{i}} \text { said (that) he } \mathrm{j} \text { had seen Fred the previous day }
$$

English has no grammatical means of distinguishing different third person referents here. In contrast, languages with logophoric systems do - we return to these in Section 3.5.

Indirect speech reports in English differ from direct speech in a number of other features. Since the speech report content of (1a) and (1b) was prior to the report by John, 
saw in both (2a) and (2b) is 'back-shifted' to the 'past perfect', or past with respect to the past, had seen. The time adverb yesterday is changed to the previous day. The optional complementizer that is a marker of syntactic link between the reporting clause and the speech report content. Appendix A contains a survey of features which serve to differentiate speech reports across languages. A list of points to be addressed in an analysis of speech reports in any language is given in Appendix B.

In this paper we focus on SHIFT IN PERSONAL DEIXIS, which is a major property distinguishing direct and indirect speech reports. Suffice it to say that in many languages it is indeed the only way of telling direct and indirect speech apart - examples include Hatam (Papuan area: Reesink, 1999, p. 105), Abun (Berry and Berry, 1999, p. 177), Nigerian Pidgin (Faraclas, 1996, p. 6) and Babungo (Schaub, 1985, p. 1). ${ }^{1}$ But is such person shift always straightforward? This takes us to the next section.

\subsection{Person shift, and coreferentiality in speech reports}

A speech report may involve:

- the Current Speaker (CS) - that is, the person who produces the speech report;

- the Original Speaker (OS), e.g. John in $(1 a, b)$ and $(2 a, b)$;

- and the participants within the speech report itself - the subject 'I' in (1a), 'he' in (1b)$(2 a, b)$, and the object 'Fred' in $(1 a, b)$ and $(2 a, b)$. There can be further participants such as the addressee, and a variety of obliques.

When a direct speech report is recast as indirect speech, and if the Original Speaker is coreferential with a Speech Act Participant within the report (that is, first person 'I' or second person 'you'), a non-third person shifts to third person - compare (1a) and (2a). If there is no coreferentiality, there is no person shift - compare (1b) and (2b).

A selection of options for coreferentiality between the Original Speaker (OS) and the participants within the speech report is given in Table 1. For the sake of simplicity, at this stage, I have not included either the option for a second person for the Original Speaker, or any ungrammatical options with the lack of shift in indirect speech reports (e.g. *John said that Paul had seen $\mathrm{me}_{\mathrm{i}}$ ).

This table contains a set of grammatical options. Further options would be ungrammatical in standard English. These involve person shift within a direct speech report. So, a sentence * John $n_{\mathrm{i}}$ said: 'He saw Paul' where 'he' refers to John would be nonsensical. A sentence *John $n_{\mathrm{i}}$ said: 'Fred saw him,' where 'him' refers to John would also be impossible, if He saw Paul and Fred saw him are direct speech reports. These examples could be grammatical only if seen as a variation on an indirect speech report with that omitted, $J_{o h n}$ said he $_{\mathrm{i}}$ saw Paul with no tense back-shift. We will see below, however, that such 'strange' speech reports - 'semi-direct speech' - are a legitimate option in some languages.

\footnotetext{
${ }^{1}$ Cross-linguistic statements within this paper are based on a comprehensive typological account of speech reports presented in the position paper for the Local Workshop on Direct and Indirect speech at the Research Centre for Linguistic Typology in 2004 (Aikhenvald, forthcoming). The data for this paper was collected over 12 years of fieldwork, mostly with speakers of the Avatip variety of Manambu. The corpus consists of over 1500 pages of transcribed texts, notes and conversations, from over 50 speakers.
} 
Table 1

Coreferentiality of the Original Speaker and the participants within speech reports

\begin{tabular}{|c|c|c|c|c|c|}
\hline \multirow[t]{2}{*}{$\mathrm{CS}$} & \multirow[t]{2}{*}{ OS } & \multicolumn{2}{|c|}{$\begin{array}{l}\text { Participants within speech } \\
\text { report }\end{array}$} & \multirow[t]{2}{*}{ Examples } & \multirow[t]{2}{*}{$\begin{array}{l}\text { Speech } \\
\text { report }\end{array}$} \\
\hline & & $\begin{array}{l}\mathrm{A} / \mathrm{S} \\
\text { ('SUBJECT') }\end{array}$ & $\begin{array}{l}\mathrm{O} \\
\text { ('OBJECT') }\end{array}$ & & \\
\hline me & John & Fred & Paul & $\begin{array}{l}\text { John said: 'Fred saw Paul' } \\
\text { John said (that) Fred had seen Paul }\end{array}$ & $\begin{array}{l}\text { Direct } \\
\text { Indirect }\end{array}$ \\
\hline me & John & John & Paul & $\begin{array}{l}\text { John }_{\mathrm{i}} \text { said: ' 'I } \mathrm{i}_{\mathrm{i}} \text { saw Paul' } \\
\text { John }_{\mathrm{i}} \text { said (that) he } \mathrm{e}_{\mathrm{i}} \text { had seen Paul }\end{array}$ & $\begin{array}{l}\text { Direct } \\
\text { Indirect }\end{array}$ \\
\hline me & John & Fred & John & $\begin{array}{l}\text { John }_{\mathrm{i}} \text { said: 'Fred saw me' } \\
\text { John }_{\mathrm{i}} \text { said (that) Fred had seen } \text { him }_{\mathrm{i}}\end{array}$ & $\begin{array}{l}\text { Direct } \\
\text { Indirect }\end{array}$ \\
\hline me & John & John & John & $\begin{array}{l}\text { John }_{i} \text { said: ' } I_{i} \text { saw myself } \\
\text { John }_{i} \text { said (that) he had seen himself }\end{array}$ & $\begin{array}{l}\text { Direct } \\
\text { Indirect }\end{array}$ \\
\hline
\end{tabular}

The Current Speaker (CS) may be coreferential with the Original Speaker, and/or with a participant within a speech report situation. A selection of relevant options is given in Table 2.

Here again, a number of further options would be ungrammatical in standard English. These involve person shift within direct speech reports which cast the Current Speaker (here 'me') as if the Current Speaker were also the Original Speaker when she is not, as in "John said: 'I $I_{\text {CurrentSpeaker }}$ saw Fred'. This may be acceptable as an indirect speech report with that omitted and no tense back-shift, but not as a direct speech report.

If I am simultaneously the Current Speaker and the subject of a statement within the speech report, the option *John said 'She $_{\text {CurrentSpeaker }}$ saw him $_{\mathrm{i}}$ ' would also be ungrammat-

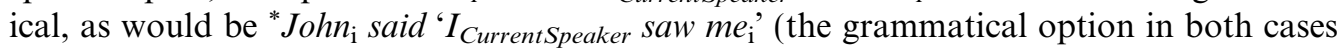
would be John said 'She saw me'). Another ungrammatical option would involve preserving the first person reference for the Current Speaker as object within a direct speech report, as in "John $n_{i}$ said ' $I_{i}$ saw me ${ }_{\text {CurrentSpeaker. }}$.

Table 2

Coreferentiality of the Current Speaker, the Original Speaker and the participants in speech reports (the Current Speaker is feminine)

\begin{tabular}{|c|c|c|c|c|c|}
\hline \multirow[t]{2}{*}{$\mathrm{CS}$} & \multirow[t]{2}{*}{ OS } & \multicolumn{2}{|c|}{ Participants within speech report } & \multirow[t]{2}{*}{ Examples } & \multirow[t]{2}{*}{ Speech report } \\
\hline & & A/S ('SUBJECT') & $\mathrm{O}$ ('OBJECT') & & \\
\hline me & me & John & Fred & $\begin{array}{l}\text { I } \mathrm{CS} \text { said: 'John saw Fred' } \\
\text { I said (that) John had seen Fred }\end{array}$ & $\begin{array}{l}\text { Direct } \\
\text { Indirect }\end{array}$ \\
\hline me & John & me & Fred & $\begin{array}{l}\text { John said 'She }{ }_{C S} \text { saw Fred' } \\
\text { John said (that) I had seen Fred }\end{array}$ & $\begin{array}{l}\text { Direct } \\
\text { Indirect }\end{array}$ \\
\hline me & John & me & John & $\begin{array}{l}\text { John }_{\mathrm{i}} \text { said 'She } \mathrm{CS} \text { saw me' }{ }_{\mathrm{i}} \\
\mathrm{John}_{\mathrm{i}} \text { said (that) I had seen him }{ }_{\mathrm{i}}\end{array}$ & $\begin{array}{l}\text { Direct } \\
\text { Indirect }\end{array}$ \\
\hline me & John & John & me & $\begin{array}{l}\text { John }_{i} \text { said 'I } I_{i} \text { saw her }{ }_{C s} \text { ' } \\
\text { John }_{i} \text { said (that) he had seen } \text { me }_{C S}\end{array}$ & $\begin{array}{l}\text { Direct } \\
\text { Indirect }\end{array}$ \\
\hline me & me & me & Fred & $\begin{array}{l}\mathrm{I}_{\mathrm{CS}} \text { said 'I } \mathrm{ISS}_{\mathrm{CS}} \text { saw Fred' } \\
\mathrm{I}_{\mathrm{CS}} \text { said (that) } \mathrm{I}_{\mathrm{CS}} \text { had seen Fred }\end{array}$ & $\begin{array}{l}\text { Direct } \\
\text { Indirect }\end{array}$ \\
\hline me & me & Fred & me & $\begin{array}{l}\mathrm{I}_{\mathrm{CS}} \text { said 'Fred saw me }{ }_{\mathrm{CS}} \text { ' } \\
\mathrm{I}_{\mathrm{CS}} \text { said (that) Fred had seen } \mathrm{me}_{\mathrm{CS}}\end{array}$ & $\begin{array}{l}\text { Direct } \\
\text { Indirect }\end{array}$ \\
\hline me & $\mathrm{me}$ & me & $\mathrm{me}$ & $\begin{array}{l}\mathrm{I}_{\mathrm{CS}} \text { said: ' } \mathrm{I}_{\mathrm{CS}} \text { saw myself } \mathrm{CS}^{\prime} \text { ' } \\
\mathrm{I}_{\mathrm{CS}} \text { said (that) } \mathrm{I}_{\mathrm{CS}} \text { had seen myself } \mathrm{CS}_{\mathrm{CS}}\end{array}$ & $\begin{array}{l}\text { Direct } \\
\text { Indirect }\end{array}$ \\
\hline
\end{tabular}


A further ungrammatical option involves casting the Current Speaker as if she were not the Original Speaker when in fact she was, as in ${ }^{*} I_{\text {CurrentSpeaker=OriginalSpeaker }}$ said 'She CurrentSpeaker=OriginalSpeaker saw Fred'. It is equally impossible to say * $I_{\text {CurrentSpeaker }}$ said 'Fred saw her CurrentSpeaker.'

These ungrammatical starred examples can be viewed as weird instances of direct speech with unexpected person shift. The starred examples discussed after Table 1 contain what looks like 'illegitimate' shift of person of the Original Speaker. Those discussed after Table 2 contain peculiar shifts of person of the Current Speaker. The value of other persons remains the same as it was produced by the Original Speaker.

Speech report constructions with such 'incomplete' person shift, also known as 'semidirect' speech, are in fact a legitimate option in a number of languages, many of them spoken in the Highlands of New Guinea. In some, semi-direct speech is obligatory. ${ }^{3}$

In summary, such semi-direct speech reports can be:

Type I. Original-Speaker-Oriented which correspond to the options discussed after Table 1

Type II. Current-Speaker-Oriented which correspond to the options discussed after Table 2

We start with a brief outline of speech reports in Manambu, a Ndu language from the Papuan area, which has both options for semi-direct speech (Section 2). In Section 3 we consider further examples of semi-direct speech documented in the literature, and the conditions under which it is used. There, we also discuss the possibility of semi-direct speech constructions in English. The last section (Section 4) contains brief conclusions.

\section{Speech report constructions in Manambu}

\subsection{Background}

Manambu belongs to the Ndu family, and is spoken by about 2000 people in five villages in the Ambunti region of the East Sepik Province of Papua New Guinea. It is a highly synthetic, predominantly suffixing and agglutinating language, with a strong tendency towards verb-final constituent order. Its morphological structure is quite complex (Aikhenvald, 2008). Manambu has contrastive word stress, and no tones.

Nouns distinguish two genders, three numbers and nine case forms. Verbs have an array of grammatical categories, including several modalities, aspects and tenses fused with person, number and gender marking; a complex system of negation; and clausechaining. Only declarative verbs are fully inflected: they can cross-reference two participants (the subject and another topical argument or oblique) and take a full array of aspect

\footnotetext{
${ }^{2}$ Other ungrammatical examples which involve lack of shift in indirect speech reports, such as ${ }^{*} J o h n_{\mathrm{i}}$ said that he $\mathrm{i}_{\mathrm{i}}$ had seen her $\mathrm{CS}_{\mathrm{CS}}$ are not included, for the sake of simplicity.

${ }^{3}$ Whether any language has indirect speech reports similar to ${ }^{*} J o h n_{\mathrm{i}}$ said that he $\mathrm{i}_{\mathrm{i}}$ had seen her $_{\mathrm{CS}}$ is an open question. In addition, if one reports speech by someone else - as in, for instance, Paul said: 'John said: "I saw Fred yesterday" " - both Paul and John will be 'original speakers'. For the sake of simplicity, we restrict most of our discussion to the situation with one original speaker.
} 
markers. Desideratives and same subject purposives do not take any person inflection. The different subject purposive cross-references just the subject.

The imperative has its own paradigm of subject marking. Importantly, there is one verb form for second person singular, dual and plural imperative. The exact reference is distinguished by using free personal pronouns: $a$-wuk (IMPV.2pers-listen) may mean 'you (singular) listen!' or 'you (dual) listen!', or 'you (plural) listen'. To disambiguate these, one can say mən a-wuk (you.masc IMPV.2pers-listen) 'you (masculine) listen!', ñan a-wuk (you.fem IMPV.2pers-listen) 'you (feminine) listen!', bar a-wuk (you.du IMPV.2pers-listen) 'you two listen!', gur a-wuk (you.pl IMPv.2pers-listen) 'you many listen!'

Direct speech reports in Manambu are highly frequent, and semantically versatile. Any speech act - statement, question or command - can be cast as a direct speech report. In contrast, indirect speech reports are restricted to reported commands, and are less semantically versatile. In Section 2.2, we address the differences between direct and indirect speech reports. 'Semi-direct' speech with incomplete person shift along the lines of Section 1.2 is considered in Section 2.3.

\subsection{Distinguishing direct and indirect speech reports}

Speech reports in Manambu are multiclausal. They are by far the most frequent clause type in Manambu discourse of all genres. An overwhelming majority of speech reports are direct speech. These aim at reproducing what has been said without any shift in personal, temporal or spatial deixis. Direct speech reports are often quotations. And, more often than not, they convey not just the words, but the intonation, the look, the gestures, the particular tone of voice and so on - depending on the 'theatrical effect' the speaker wants to produce. A direct speech report can be separated from the reporting clause by a short pause.

Direct speech reports in Manambu cover statements, reported commands and reported questions. Indirect speech reports exclusively cover reported commands. The distinguishing properties of direct and indirect speech reports are listed in Table 3. Most of these

Table 3

Direct and indirect speech reports in Manambu: a comparison

\begin{tabular}{|c|c|c|c|}
\hline \multicolumn{2}{|c|}{ Properties of speech report } & \multirow{2}{*}{$\begin{array}{l}\text { Direct speech reports } \\
\text { none }(3),(5),(6),(7)\end{array}$} & \multirow{2}{*}{$\begin{array}{l}\text { Indirect speech } \\
\text { reports } \\
\text { yes }(14),(15),(16)\end{array}$} \\
\hline 1. & Shift in personal, temporal or spatial deixis & & \\
\hline 2. & Co-extensive with a clause & not necessarily (3), (5) & yes $(14),(15),(16)$ \\
\hline 3. & Speech report introducer ata 'then, thus' & yes $(3),(4),(5),(6),(8)$ & no \\
\hline 4. & A pause between reporting verb and the speech report & optional (3) & no \\
\hline 5. & Vocatives and exclamations & yes (4) & no \\
\hline 6. & Discontinuous speech report & possible $(5)$ & no \\
\hline 7. & $\begin{array}{l}\text { Speech report can precede or follow the reporting } \\
\text { clause }\end{array}$ & yes $(3)-(5)$ & $\begin{array}{l}\text { always precedes } \\
(14),(15),(16)\end{array}$ \\
\hline 8. & Types of speech act reported & $\begin{array}{l}\text { statement (4)-(5), } \\
\text { question }(9), \text { command } \\
\text { (3) }\end{array}$ & $\begin{array}{l}\text { only command } \\
(14),(15),(16)\end{array}$ \\
\hline 9. & Can be conventionalized & yes $(8)$ & no \\
\hline 10. & Speech report implies a speech event & not necessarily (10)-(13) & always \\
\hline 11. & $\begin{array}{l}\text { Different forms of verb in speech reports mark } \\
\text { involvement of the Original Speaker in performing } \\
\text { activity }\end{array}$ & no & possible (15), (16) \\
\hline
\end{tabular}


properties are mentioned in Appendix A as potentially criterial for distinguishing direct and indirect speech reports cross-linguistically.

The numbers of examples from Manambu which illustrate the points in the Table 3 are given in brackets.

\subsubsection{Direct speech reports, and their properties in Manambu}

As expected, a direct speech report does not display any shift in personal, temporal or spatial deixis to fit in with the perspective of the reporter. This is illustrated in (3). Here, the locative kalam 'here' reflects the location of the female addressee's 'staying'. (We can recall, from Section 2.1, that the second person imperative does not distinguish gender and number of the addressee: this is why the second person imperative form adakw is used.) A direct speech report is typically introduced with the demonstrative adverb ata 'then, thus' within the reporting clause with the verb wa- 'say, speak'. There is an optional pause between the speech report and the reporting verb. (Here and throughout the paper, clauses are in square brackets. Speech reports are in italics.)

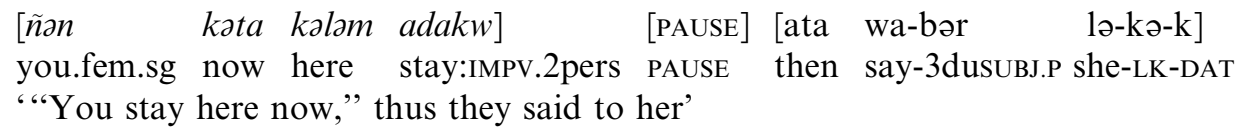

A direct speech report can be co-extensive with a clause, or a sentence. It may contain part of a clause, for instance, just a vocative, as in (4). Or it may consist of several sentences and be discontinuous, as in (5). Such discontinuity only occurs on clause boundaries.

$\begin{array}{llll}\text { [gra-n] } \quad \text { ata wa-na }] & {[\text { wun- } a-d z} & \text { mam-eee }] \\ \text { cry-SEQ then say-ACT.FOC+3fem.sgSuBJ.NP } & \text { I-LK-masc.sg } & \text { older.sibling-VOC } \\ \text { 'She said crying: "Oh my older brother!", } & & \end{array}$

$\begin{array}{lllll}{[d \partial-k \partial-k} & \text { vo } & \text { ma: }] & {[\text { wun }} & \text { warya- } u \\ \text { he-OBL-DAT } & \text { see:NEG } & \text { NEG } & \text { I } & \text { fight-1sgPERM }\end{array}$

$\begin{array}{ll}\text { [ata } & \text { wa-də-di] } \\ \text { then } & \text { say-3masc.sgsubJ.P-3plobJ.P }\end{array}$

[do-ka-wa kata warya-k yi-na-dawun-ək]

he-OBL-COM now fight-PURP.Ss go-ACT.FOC-1masc.sgSUBJ.P-CONF

" "She is not to see him, let me fight," thus he said to them, "I am going to fight with him now",

Speech reports can precede or follow the framing clause containing the speech verb, with a slight preference for the former. (In the corpus about $70 \%$ of direct speech reports precede the framing clause.)

Direct speech covers all speech acts. A statement was illustrated in (5), while (6) features a command. Direct speech reports are preferred in reported commands if the Original Speaker chooses to preserve the exact wording of the command. 
If a command is part of a larger speech report which contains a justification for the command, a direct speech report is a preferred strategy. The reported command in (6) was accompanied by an explanation in (7): the older brother felt he ought to be killed by the enemy before they killed his younger sibling:

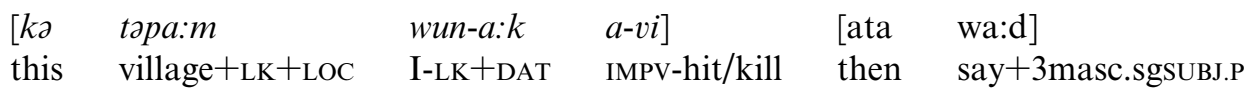

"'Kill me in this village," thus he said"

(7) $\left.\begin{array}{llll}\text { wun } & \text { kiya-u } & \text { ta:y }\end{array}\right]$
I $\left.\begin{array}{lll}\text { wun } & \text { ma:m }\end{array}\right]$
'Let me die first, I am the older brother'

A conventional greeting which has the form of a command is always cast as a direct speech report:

\begin{tabular}{|c|c|c|c|}
\hline & $m a: y]$ & [ata & wa:1] \\
\hline well & go & then & say +3 fem.sgsuBJ.P \\
\hline
\end{tabular}

" "Good-bye (lit. you go well)," she said'

A question within a direct speech report is illustrated in (9).
[[ñ $\quad$ kas $] \quad$ wa-ku $]$
sun how.much say-COMPL:SS ask+3masc.sgSUBJ.P
'He asked what time it is (lit. He asked saying "What time is it?")'

This example illustrates an additional point: the verb wa- 'say, speak' is the only speech verb which consistently introduces speech reports. ${ }^{4}$ Other verbs referring to speech acts (e.g. 'ask' in (9), and 'cry' in (4)) can only occur with a speech report if they are preceded by a dependent medial clause containing the verb $w a$ - which, in its turn, introduces the speech report, as in (9). In such cases the direct speech report introducer ata 'then, thus' can be omitted: it is indeed omitted in (9), but not in (4).

Direct speech reports in Manambu are extremely versatile: besides reporting an actual speech event, they are employed to express internal speech and thought, desire and intention of third person, warning, reason and purpose. In these cases, ata is often omitted.

Example (10) is cast as a direct speech report. It did not involve any actual speech act. As I was coming downstairs with a loaded camera (without saying anything, but with a

\footnotetext{
${ }^{4}$ Manambu has three verbs of speech - bla- (allomorph bəl-) 'say/tell (something)', yi- 'say X, speak (a language)', and $w a$ - 'say, tell'. Of these, only the verb $w a$ - occurs with speech reports of any kind. This is in contrast to those languages where the choice of reporting verb may differentiate speech reports (see Appendix A). The verb $y i$ - occurs with just a few interjections as speech reports, as in $a y y i-d a-d$ (INTERJECTION say-3plsUBJ.NP3 masc.sgoBJ.NP) 'they shouted' (lit. they said ay), and with a noun phrase object, e.g. yarək yi-da-d (news say3plsuBj.NP-3masc.sgoBj.NP) 'they told the news'. The verb bla- can take a limited number of noun phrase objects, including kudi 'language', ma:j 'talk', yanu 'witchcraft' (e.g. ñaura kudi bla- (Iatmul language speak-) 'to speak Iatmul language').
} 
clear intention to take pictures, as requested prior to that), my adopted sister said to make sure the girls were ready for me to take their picture.

$$
\begin{array}{lll}
{[\text { kayik }} & k u r \partial k] & {[\text { wa-na }]} \\
\text { picture/image } & \text { do/get+PURP.ss } & \text { say-ACT.FOC+3fem.sgsUBJ.NP }
\end{array}
$$

'She wants or intends to take pictures (lit. She says "(I) am intending to take pictures")'

One day a duckling was brought inside the house. The cat did not dare touch him, but its desires were clear from the way it looked at the bird. (11) - a comment on this - could not have referred to an actual speech act: cats do not talk.

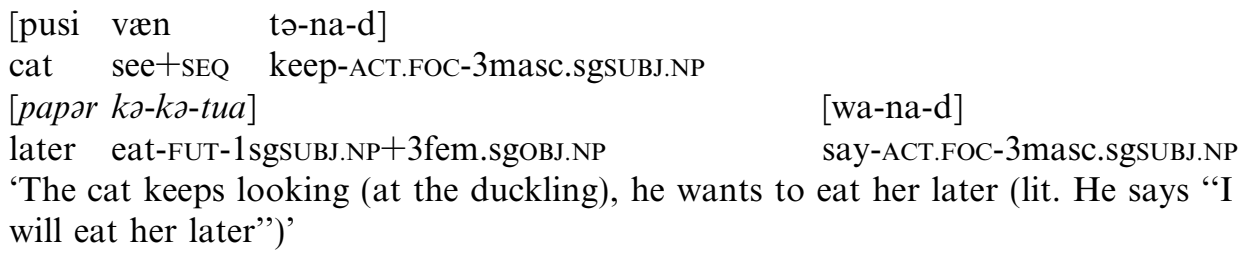

Direct speech reports are the only way of expressing someone's intention - Manambu has no other way of expressing the notion of 'intending', or 'wanting'. They can also express reason, as in (12):

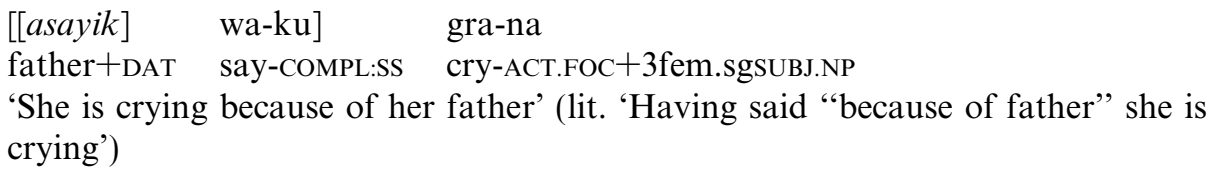

This was said about a baby who was crying because her father had gone off to a meeting, leaving her. The baby could not talk, so there was no actual speech act involved. Similarly, in (13), a speech report is a way of expressing the end result of counting: this was a question to a mother about the age of her toddler:

$$
\begin{array}{ll}
{\left[\begin{array}{ll}
n a b i & k a s
\end{array}\right]} & \text { wa-na-d } \\
\text { year how.many } & \text { say-ACT.Foc-3masc.sgsuBJ.NP } \\
\text { 'How old is he? (lit. 'How many years does he say?')' }
\end{array}
$$

Internal speech and thought are also cast as direct speech reports, using the same verb $w a$ - 'say' whose meaning can be viewed as far more general than simply reporting a speech act.

Such versatility is hardly unusual. Multifunctional speech reports are a feature Manambu shares with a number of other Papuan and Austronesian languages. Direct speech reports express thinking, desire, intention and cognition in Maybrat (Dol, 1999, pp. 228-230), and also purpose in Tauya (MacDonald, 1990a), in Korowai (van Enk and de Vries, 1997, pp. 104-105), in Kombai (see de Vries, 1990), and also in a number of Western Austronesian languages (Klamer, 2000). Lower Grand Valley Dani also employs direct speech reports to express the speaker's intention (Bromley, 1981, p. 245). Thought 
and motives are represented as quoted speech in languages of the Marind and Awyu families (Drabbe, 1955, 1957, 1959). ${ }^{5}$

\subsubsection{Indirect speech reports, and their features in Manambu}

In contrast to direct speech reports which are not limited to any speech act, indirect speech reports cover just reported commands. An alternative to (6) is (14). Then, the exact words of the actual command are not preserved. The predicate in reported commands appears in the different subject purposive, if the Original Speaker is not involved in performing the activity. The person shift in the verb 'hit/kill' and in the spatial deictic are indicative of an indirect speech report.

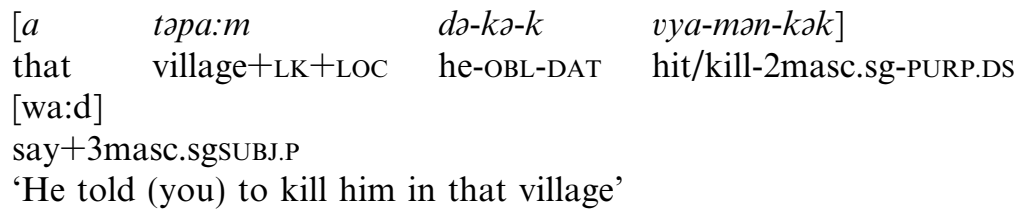

Indirect speech reports cannot contain the speech report introducer ata 'then, thus'. A speech report is always preposed to the reporting verb $w a$ - and there is no pause. Unlike direct speech reports, an indirect speech report cannot be discontinuous, consist of more than one clause, or be shorter than a clause. If the subject of the speech report is different from the Original Speaker, different subject purposive is used, as in (15). The Original Speaker is not going to join the subject of the speech report in 'eating sago'.

\begin{tabular}{|c|c|c|}
\hline $\begin{array}{l}{[n a: g w} \\
\text { sago }\end{array}$ & $\begin{array}{l}\text { ka-la-kakak] } \\
\text { consume-3fem.sg-PURP.DS }\end{array}$ & $\begin{array}{l}\text { [wa-tua-1] } \\
\text { say-1sgsuBJ.P-3fem.sgoBJ.P }\end{array}$ \\
\hline
\end{tabular}

But if the original speaker is involved in performing the required activity, the same subject purposive is used within the indirect speech report, as in (16):

$$
\begin{array}{lll}
{\left[\begin{array}{ll}
n a: g w & k \jmath k a: k
\end{array}\right]} & {[\text { wa:d] }} \\
\text { sago } & \text { eat+RED+PURP.ss } & \text { say+3masc.sgsubJ.P } \\
\text { 'He told (them) to eat sago' (he was eating with them) }
\end{array}
$$

This is somewhat similar to the phenomenon of logophoricity (see Section 3.5).

\footnotetext{
${ }^{5}$ These do not exhaust potential polysemies of reporting verbs. In Australian languages, one verb often means 'do' and 'say'. Ngalakan yini- means 'say' and 'do thus' (it may even be accompanied by a gesture if it indexes something present in the speech situation) (Merlan, 1983, p. 152). The basic meaning of $m a$ in Ungarinjin is 'do'. This verb also occurs with direct speech reports, and can then be translated as 'say'. But given that for the Ungarinjin, 'speech is a form of action, perhaps its most salient form', 'do' is arguably still the verb's core meaning (Rumsey, 1982, pp. 158-163, 1990). A somewhat different construction with the same verb is used for intention and causation. This same root is also used for internal speech, that is, thought, in Bunuba. In Tuvaluan, the verb used in direct speech reports has a general meaning 'do' and also appears in desiderative, causative and purposive constructions (Besnier, 2000, p. 657). And in the Lolovoli dialect of North-East Ambae, a direct speech report construction is used for imitating another person's action (Hyslop, 2001, p. 299).
} 
In contrast to direct speech reports which have a number of semantic extensions, indirect speech reports in Manambu always imply an actual speech event. There are no conventionalized uses of indirect speech reports (see (8) above, for a conventionalized direct speech report).

In terms of their syntactic status, neither the direct speech nor the indirect speech report is an object of the verb $w a$ - 'say, speak' since they cannot be cross-referenced on the verb as a direct object or an oblique (such as, for instance, location or manner) would. The verb $w a$ - can be used either transitively or intransitively; when used transitively, the addressee can be cross-referenced - this is illustrated in (5) ('he-said-to-them'). Speech reports are best considered a special type of obligatory grammatical relation different from any other (see Mittwoch, 1985; Partee, 1973; Munro, 1978, 1982, on the special syntactic status of speech reports).

\subsection{Semi-direct speech reports in Manambu}

Direct and indirect speech reports are very common in Manambu. Semi-direct speech constructions are less frequent, but nevertheless are a recurrent and acceptable pattern. Of the total of direct speech reports in the corpus, semi-direct speech reports account for about $10 \%$. All involve free personal pronouns.

\subsubsection{Formal properties of semi-direct speech}

While in indirect speech reports the person reference 'shifts' to the perspective of the Current Speaker, there is no such shift in direct speech reports. In semi-direct speech, the reference for some participants is shifted, while for others it is not.

Example (18) illustrates such an 'intermediate' speech report in Manambu. Before the two brothers had left the house, they said (17) to their sister. This is cast as a direct speech report within the narrative. The imperative, 'you-stay', is underlined.
$[\tilde{n} \partial n$
ata wiya:m $m$ adakw
stay:IMP
an $m a:$
ma: $\quad$ kami:k $y i-t a k]$
[wa-ku] [ata yi-bər]
say-COMPL:Ss then go-3dusuBJ.P
"'You stay at home, let us two go fishing again," having said (this) the two went off"

We can recall, from Section 2.1 above that second person imperative in Manambu does not distinguish number or gender of the addressee. The second person free pronoun ñan 'you feminine' appears here: it is now fully clear that the girl is the addressee.

Later in this story, a stranger approaches the girl and makes an attempt to kidnap her. She tells him that she will stay at home after what her brothers have told her to do. This is how she reports her brothers' speech:

\begin{tabular}{|c|c|c|}
\hline [wun & wiya:m & [wa-bər-kəkəb] \\
\hline I:IND.SP.REP & house+LOC stay:IMPV.2pers:DIR.SP.REP & say-3du-AS.SOON.AS \\
\hline [wiya:m & $k w a-k \partial-n a-w u n-\partial k$ & $w u n]$ \\
\hline house+LOC & stay-FUT-ACT.FOC-1fem.sgSUBJ.NP-CONF & I \\
\hline
\end{tabular}

'Since the two told me to stay (lit. I you-stay) in the house I will stay in the house' 
Example (18) contains reported speech within reported speech. This example, like further instances below, comes from a story told by a narrator. However, the narrator's identity as a 'Current Speaker' is of no relevance to person shift. The Original Speaker (i.e. the girl) in (18) is the 'second level' reporter, which can be considered a 'surrogate' Current Speaker.

The speech report in (18) is an example of Type I semi-direct speech. The speech report contains a token of direct speech report: the second person imperative form of the verb. This is exactly what the brothers had said to the girl, in (17) in the direct speech report (hence the note DIR.SP.REP in the gloss). On the other hand, the speech report in (18) contains one feature of indirect speech: the free pronoun has been shifted to first person 'I', to fit in with the perspective of the 'surrogate' Current Speaker, that is, the girl (hence the note IND.SP.REP in the gloss). The token of indirect speech is coreferential with the Original Speakers - the two brothers.

The differences and similarities between a direct speech report in (17) and a semi-direct report in (18) are summarised in Scheme 1.

\section{Scheme 1. Differences between direct and semi-direct speech reports in Manambu (17-18)}

DIFFERENT FROM DIRECT SPEECH REPORT:

change of pronoun $\tilde{n} \partial n$ 'you' to wun 'I' SAME AS DIRECT SPEECH REPORT:

Semi-direct speech reports found in the corpus do not always contain commands. They can be declarative statements. A mother (who has recently died but keeps an eye on her orphaned children) tells her son that the things belonging to him and his sister are here:

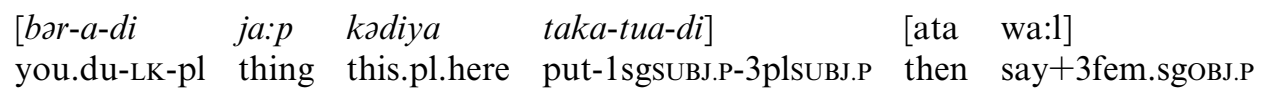
"She said thus: "The things belonging to you two I put here",

The son then reports to his sister what the mother had said:

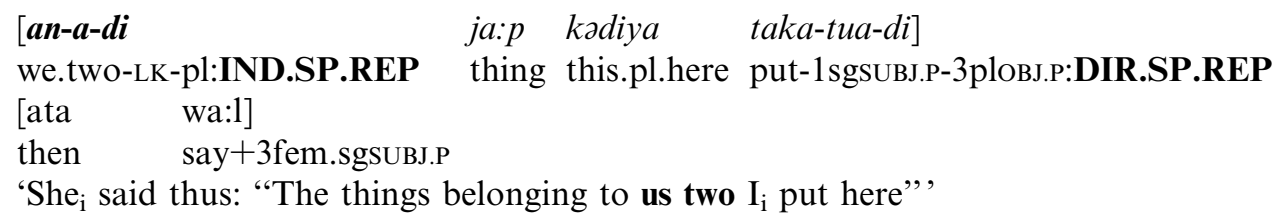

'She $\mathrm{i}_{\mathrm{i}}$ said thus: "The things belonging to us two $\mathrm{I}_{\mathrm{i}}$ put here",

Just as in (18), the person shift within the speech report is incomplete. The first person singular cross-referencing on the verb is exactly the same as in the original speech, in (19), and thus can be considered a token of direct speech (DIR.SP.REP in the gloss). The possessive pronoun ('belonging to us two') is 'adjusted' to the Original Speaker's (that is, the son's) perspective, and can thus be considered a token of an indirect speech report (IND.SP.REP in the gloss). The spatial deixis has not been 'shifted' - the form 'here' is the same in both (19) (what the mother had said) and in (20) (her speech reported by her son). This is another example of semi-direct speech of Type I: the person reference of the subject of the speech report has been partially adjusted to the perspective of the Original Speaker (the boy). 
A speech report with incomplete person shift may contain an uninflected verb - a desiderative form with no person cross-referencing, in (21). A man says to two sisters, in an attempt to frighten them:

\begin{tabular}{|c|c|c|c|c|c|}
\hline$[$ wun & $k \partial-k \partial-t u a-d i g u r-\partial k]$ & {$[w u n$} & kata & bra:m & $k \partial-k \partial r]$ \\
\hline & eat-FUT-1 sgsUBJ.NP-2ploBJ.NP-CONF & $\mathrm{I}$ & now & you.two $+\mathrm{LK}+\mathrm{OBJ}$ & eat-DES \\
\hline
\end{tabular}

The younger sister is scared, and says (22) to her older sister, recasting the man's speech as follows:

\begin{tabular}{|c|c|c|}
\hline [lə-kə & mamək & wa-lə-1] \\
\hline she-LK+fem.sg & elder.sibling $+\mathrm{LK}+\mathrm{DAT}$ & say-3fem.sgsUBJ.P-3fem.sgOBJ.P \\
\hline$[a-d a$ & [pause]] & {$[$ wun } \\
\hline DEM.DIST-masc.sg & [pause] & I:DIR.SP.REP \\
\hline an-a:m & $k \partial-k \partial r]$ & $w a-n a-d]]$ \\
\hline du-LK + OBJ:IND & eat-DES & thus say-ACT.FOC-3masc.sgSUBJ.NP \\
\hline
\end{tabular}

The girl did not quote the man's speech exactly - she partly recast it, transforming it into a semi-direct speech report. The subject reference ('I') is not adjusted to her, that is, the 'Original Speaker's' perspective. This is a token of direct speech report, and is exactly the same as in the man's original speech in (21). So is the temporal deictic, kata 'now'. In contrast, the object referent ('us two') is adjusted to the perspective of the girl as the Original Speaker, and is a token of indirect speech. This is another example of semi-direct speech report of Type I.

Examples (17)-(22) come from traditional stories, told by a story-teller. As mentioned above, for each of (18), (20) and (22), one can postulate two sets of 'Original Speakers', if the story-teller is to be considered a Current Speaker. For instance, in (18) brothers are the 'primary' Original Speakers whose speech appears in (17), and the girl who is reporting their speech can be treated as a 'secondary' Original Speaker. The secondary Original Speaker can be considered, for all effects, a 'surrogate' Current Speaker, since the perspective of the story-teller appears to be irrelevant for person shifts. The reference within the speech report is shifted to that of this Current Speaker - the girl in (18), 'us two' in (20), and in (22).

Similar constructions are used in spontaneous conversations where there is no speech report within a speech report. A mother told her child to listen to the care-taker:

$\begin{array}{lll}{[s a ! \quad \text { man }} & l a-k \partial-k & a-w u k] \\ \text { hey! you.masc } & \text { she-OBL-DAT } & \text { IMPV.2pers-listen } \\ \text { 'Hey! You listen to her!' } & \end{array}$

Later on, the care-taker grumbled at the child, reminding the child of what the mother had said, and using the same imperative intonation and the same interjection $s a$ 'Hey!' as the one in (23):

$\begin{array}{llll}{[s a ! \text { mon }} & \text { wun- } a: k & a-w u k] & \\ \text { hey! you.masc I-LK+DAT:IND.SP.REP } & \text { IMPV.2pers-listen:DIR.SP.REP } \\ \text { [ata wa-na] } & \text { [mən } & \text { ma: } & \text { wa:k] } \\ \text { then say-ACT.FOC+3fem.sgSUBJ.NP } & \text { you.masc } & \text { NEG } & \text { listen+NEG } \\ \text { "Hey! You listen to } \text { me }_{\mathrm{i}} \text { !" } \text { she }_{\mathrm{j}} \text { thus said, you are not listening!" } & \end{array}$


As in the examples (18), (20) and (22) above, the semi-direct speech report in (24) has features of both direct and indirect speech: second person imperative is a token of direct speech report, and the form of the addressee, 'me', is a token of indirect speech (the mother had said 'her', in (23)). The interjection sa! 'Hey!' is another token of direct speech in (24). However, (24) differs from the other examples of semi-direct speech discussed so far in that the token of indirect speech reflects the perspective of the real Current Speaker (the care-taker), and not that of the Original Speaker (the mother). (24) is an example of a semi-direct speech report of Type II: the person shift is done here in agreement with the person of the Current Speaker: the Current Speaker - coreferential with the addressee in (24) - is expressed as 'me'.

The Current Speaker (that is, the narrator of the story) was of no relevance for person marking in (18), (20) and (22). So, the person of a participant within a speech report was shifted, to mark coreferentiality with the secondary Original Speaker, a 'surrogate' Current Speaker.

The imperative intonation of (17) and of (23) was preserved in the semi-direct speech reports in (18) and (24). This 'mimicking' effect is a feature of direct, and not of indirect, speech reports both in Manambu (see Table 3), and cross-linguistically (see Wierzbicka, 1974; Clark and Gerrig, 1990).

Within a semi-direct speech report, free pronouns shift to fit in with the perspective of the Original Speaker (tokens of semi-direct speech of Type I, exemplified in (18), (20), and (22)) or with that of the Current Speaker (tokens of semi-direct speech of Type II, exemplified in (24)). Tokens of direct speech can be free pronouns, or bound forms of pronominal cross-referencing.

All the instances of semi-direct speech always imply an actual speech event. This is in contrast to direct speech reports which have a plethora of other meanings, to do with intention, reason and counting - see (10-13) above. The speech report introducer ata is optional (see (22)) These features bring semi-direct speech reports closer to indirect than to direct speech. Semi-direct speech reports of Type I and Type II do not show any differences between themselves with respect to any of these features.

Table 4 features a comparison between semi-direct, direct, and indirect speech reports, in terms of the defining properties outlined in Table 3 above.

The person shift in semi-direct speech is partly shared with direct speech, and partly with indirect speech. Of the further 10 properties differentiating direct and indirect speech reports, semi-direct speech reports share four with direct speech, and four with indirect speech. Semi-direct speech reports occur only in statements and commands (but not in questions), while indirect speech is limited to commands, and direct speech may contain commands, questions, or statements (property 8). Discontinuous semi-direct speech reports have not been attested (property 6). That is, semi-direct speech reports indeed occupy a 'middle ground' between direct and indirect speech.

Semi-direct speech is recognizable through the shifts in personal deixis, rather than in spatial or temporal deixis. The conditions under which semi-direct speech occurs in Manambu provide a partial explanation.

\subsubsection{How to use a semi-direct speech report in Manambu: a summary}

All the instances of semi-direct speech in Manambu fall into two types, in agreement with Section 1.2 above: 
Table 4

Semi-direct, direct and indirect speech reports in Manambu: a comparison

\begin{tabular}{|c|c|c|c|}
\hline Properties of speech report & \multirow{2}{*}{$\begin{array}{l}\text { Direct speech } \\
\text { no }\end{array}$} & \multirow{2}{*}{$\begin{array}{l}\text { Semi-direct } \\
\text { partial: shift in } \\
\text { free pronouns }\end{array}$} & \multirow{2}{*}{$\begin{array}{l}\text { Indirect } \\
\text { speech } \\
\text { yes }\end{array}$} \\
\hline 1. Shift in personal, temporal or spatial deixis & & & \\
\hline 2. Co-extensive with a clause & \multicolumn{2}{|c|}{ not necessarily } & yes \\
\hline 3. Speech report introducer $a t a$ 'then, thus' & \multicolumn{2}{|c|}{ yes (as in (22)) } & no \\
\hline 4. A pause between reporting verb and the speech report & \multicolumn{2}{|c|}{ optional } & no \\
\hline 5. Vocatives and exclamations & \multicolumn{2}{|c|}{ yes } & no \\
\hline 6. Discontinuous speech report & possible & \multirow{2}{*}{\multicolumn{2}{|c|}{$\begin{array}{l}\text { not attested no } \\
\text { always precedes }\end{array}$}} \\
\hline $\begin{array}{l}\text { 7. Speech report can precede or follow the reporting } \\
\text { clause }\end{array}$ & yes & & \\
\hline 8. Types of speech acts reported & $\begin{array}{l}\text { statements, } \\
\text { questions and } \\
\text { commands }\end{array}$ & $\begin{array}{l}\text { statements and } \\
\text { commands }\end{array}$ & $\begin{array}{l}\text { only } \\
\text { commands }\end{array}$ \\
\hline 9. Can be conventionalized & yes & \multicolumn{2}{|l|}{ no } \\
\hline 10. Implies a speech event & not necessarily & \multicolumn{2}{|c|}{ always } \\
\hline $\begin{array}{l}\text { 11. Different forms of verb in speech reports mark } \\
\text { involvement of the Original Speaker in performing } \\
\text { activity }\end{array}$ & no & \multicolumn{2}{|c|}{ possible } \\
\hline
\end{tabular}

Type I. The secondary Original Speaker - or the surrogate Current Speaker - is involved in the speech report, as the subject of an intransitive verb (18), as the possessor (20), or as the object (22). The 'real' Current Speaker (that is, the narrator of the story) is of no relevance in the person shift.

Type II. The Current Speaker is involved in the speech report, as the object (24).

In all the examples, the tokens of indirect speech are free pronouns, while the tokens of direct speech can be free or bound.

The use of semi-direct speech as an alternative to either direct or indirect report is not obligatory. Rather, it has a pragmatic effect: it occurs in situations when the speaker is under stress and particularly focussed on their own well-being. In (18), the girl is about to be kidnapped by a stranger. In (20), the two orphaned children are being robbed of their things by their nasty cousins, which makes them concerned about their things and where they are. In (22), the girl is afraid of being devoured by a man. And in (24), the care-taker is desperate because the naughty child would not listen. Examples (18)-(22) come from the climactic parts of narratives each of which is crucial for the rest of the story. Semi-direct speech is a stylistic device; it does not have the function of disambiguating who did what to whom.

That is, semi-direct speech can thus be considered a strategy for marking the involvement of the Original Speaker or of the Current Speaker in a situation which affects them (note that either one or the other is marked as a first person). The function of semi-direct speech reports is to allow the Current Speaker or the narrator to simultaneously 'index' two speech events: the current one and the former one. This tends to happen when the former speech event is relevant to the current situation, or is the climactic part of the story, or when it is appropriate to highlight the relevance of the participants in the speech event. This may be why semi-direct speech is focussed on person shift, rather than on shifts in time and space. ${ }^{6}$

\footnotetext{
${ }^{6}$ I am grateful to Carol Genetti for suggesting this idea.
} 


\section{Beyond Manambu: semi-direct speech world-wide}

Semi-direct speech can be a stylistic, or a discourse-organizing option, as in Manambu and in a number of languages from Africa and from the New Guinea area (Section 3.1). Or it can be obligatory, under certain conditions (Section 3.2).

\subsection{Optional semi-direct speech}

The phenomenon of semi-direct speech as an alternative to direct and indirect speech was first described for African languages. While in indirect speech reports the person reference must 'shift' to the perspective of the narrator, there is no such shift in direct speech reports and in quotations. And in semi-direct speech, the reference for some participants is shifted, while for others it is not (see Hedinger, 1984; Jackson, 1987; Noss, 1988; and Wiesemann, 1990).

We first discuss semi-direct speech of Type I, whereby person marking within a semidirect speech report can be shifted to the perspective of the Original Speaker. We then consider semi-direct speech of Type II, whereby the person reference is shifted to the perspective of the Current Speaker.

\subsubsection{Semi-direct speech of Type I: Person shift to the perspective of the Original Speaker}

An oft-quoted example of semi-direct speech comes from Aksose (a Bantu language from Cameroon: Hedinger, 1984, pp. 91-92). (25) illustrates direct speech, and (26) contains a straightforward indirect speech report. Note that in Akosse any speech report is preceded by a reporting particle (bán in (25) and (26)) which distinguishes person and number of the Original Speaker. The direct speech report contains a vocative phrase: this is a typical feature of direct speech, but not of indirect speech reports:

Akoose

[Bé-lángé bá nén bán] [à-mwế'é bán sê-dàź nyí à-wón] they-told them this RP:pl vOC-friends RP:pl we-like you to-marry "They said to them, "Friends, we would like to marry you",

$$
\begin{aligned}
& \text { [éč ê jgòndédè é-kwénténé bán] [bé-'wón b̀̀ } \\
& \text { those girls they-agreed RP:pl they-will.marry them } \\
& \text { 'Those girls agreed to marry them' (Lit. Those girls agreed (saying that) they will }
\end{aligned}
$$

Another option is a semi-direct speech report (called 'combined speech' by Hedinger, 1984, p. 92), shown in (27). The Original Speaker is referred to with a third person pronoun. Had it been direct speech, first person would be expected. This is thus a token of indirect speech. The addressee is referred to with a second pronoun, just as in the original speech. This is a token of a direct speech report. In the first clause of the speech report, the complex pronoun ('you and she') combines a token of direct speech report ('you') and that 
of an indirect speech report ('she'). The second person plural agreement on the verb is a token of direct speech, and so is the vocative form of 'husband'.

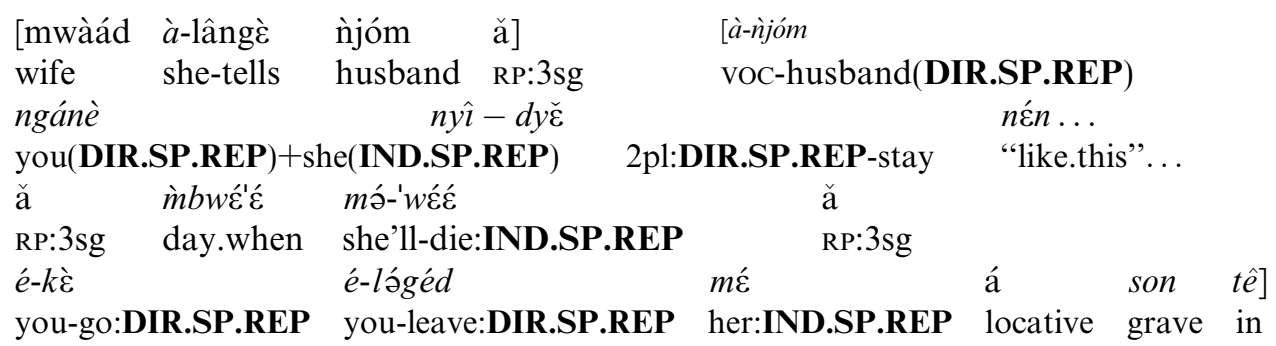

'The wife said to her husband, "Husband, since we have stayed like this ... the day when I die, go and put me in a grave", (lit. "Husband, since you and she youplural-have stayed like this, the day when she dies, you go and you put her in a grave')

Vocative phrases can occur in semi-direct speech reports in Akoose, just as they do in direct speech. This is hardly surprising, since vocatives 'refer' to the addressee, whose marking is the same in direct and in semi-direct reports. ${ }^{7}$ Whether semi-direct speech shares any further features - such as temporal, spatial and deictic reference - with direct and/or with indirect speech reports remains an open question (as noted by Hedinger, 1984, p. 94).

Using a semi-direct speech report in lieu of indirect or direct speech in Aksose, Gbaya (Noss, 1988, pp. 105, 111) and other African languages (Wiesemann, 1990, pp. 77-78) is the speaker's choice. As Noss (1988, pp. 110-111) observed for Gbaya narratives, the interplay of direct, indirect and semi-direct ('combined') discourse is a literary device used by the performer 'to develop his plot'. In Wiesemann's (1990, p. 78) words, this reflects 'a manner of speaking current in conversation' - as a stylistic option.

The use of tokens of direct and of indirect speech in Akosse is similar to Manambu in that free pronouns appear as tokens of indirect speech, while bound pronouns are tokens of direct speech. The complex free pronoun ('you and she' in (27)) combines both.

A significant difference between choice of tokens of direct and indirect speech reports in Aksose and Manambu lies in the treatment of the Original Speaker in Type I of

\footnotetext{
${ }^{7}$ Additional complications to do with logophoricity in Akosse - largely independent of semi-direct speech - are discussed in Hedinger (1981, 1984). Some languages, such as Goemai (Chadic: Hellwig, 2006, forthcoming), have a special kind of speech report construction with a special set of logophoric pronouns in the speech report; their choice depends on coreferentiality between the subject of the reporting clause and that of speech complement. Such constructions combine properties of indirect speech (the use of logophoric, rather than independent pronouns) and of direct speech (lack of shift of any deictic categories other than person). A speech report can contain vocatives and interjections, and can even mimic the original author - this makes it similar to what we expect 'direct speech' to be. Such speech reports are different from semi-direct speech reports discussed here in that they involve logophoric markers. In addition, Goemai also has indirect speech reports (a subtype of complement clauses), and emerging direct speech reports, as an innovation widespread in the speech of young speakers of this language.
} 
semi-direct speech. In Manambu, the Original Speaker is cast as first person, while in Akoose this is cast as third person. ${ }^{8}$

\subsubsection{Semi-direct speech of Type II: Person shift to the perspective of the Current Speaker}

Semi-direct speech as an optional choice has been documented for a number of languages from the Papuan area (many of them from the Highland regions of New Guinea). Unlike Manambu and the African languages, all these Papuan languages typically have just direct speech reports, and no indirect speech report as an alternative option.

In all semi-direct speech report constructions the Current Speaker is involved in the speech report. The reference to the Current Speaker is shifted to their perspective (and not to that of the Original Speaker).

Consider (28), from Usan (Numugenan family, Madang-Adalbert range: Reesink, 1993, p. 220). The Current Speaker ('I') is the addressee within the speech report; it is expressed with a token of indirect speech report ('to me') fused with the imperative

\footnotetext{
8 This goes hand-in-hand with the statement by Donald Webster, about Abidji (Kwa, Ivory Coast): 'Any reference to the speaker of a quotation inside the quotation is made by indirect reference, and any reference to the person spoken to is made by direct reference' (Grimes, 1975, p. 321). Similar examples have been reported by Hyman (1978), for Aghem, by Perrin (1974), for Mambila, by Hill (1995) for Adioukrou, and by Jackson (1987) for Tikar.

Instances of optional semi-direct speech occur in other languages. An example is found in Old Russian (Fennell and Obolensky, 1969, p. 33), in the Tale about Boris and Gleb (c. early 1200):

(i) $\mathrm{Se}$

slyshavshi, Novgorodcy

this+neuter.ACC having.heard Novgorodians.NOM.PL

[jako

that

zautra

next.day

re: ̌̀ a Yaroslav-u,

said Yaroslav-DAT.SG

perevezemsja na nj]

go.across+1pl.FUT:DIR.SP.REP onto him:IND.SP.REP

'Having heard this, Novgorodians said to Yaroslav, (that) the next day we would go across onto you' (lit. 'that we will go across onto him')
}

To what extent such semi-direct speech structures were common in Old Russian is an open question. They are not mentioned in the existing grammars where speech reports are discussed only very briefly (see Vlasto, 1986, pp. 203-205, Borkovskij and Kuznetsov, 1965, p. 525; and Matthews, 1960, pp. 222-223). I am grateful to Jonathan Clarke for drawing my attention to this example, and to Noel Brackney and Ian Press for commenting on it.

Galo (Tibeto-Burman: Post, 2007) displays a similar structure: the object pronoun, '3-ACC', is a token of indirect speech, while the 'self-directed' imperative form (which can be roughly translated as 'cut-me-off') is a token of direct speech:

(ii)

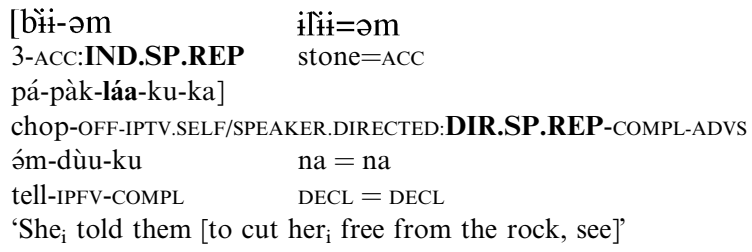

MacDonald (1990a, p. 35) mentions semi-direct speech in Tauya (Brahman family, Papua New Guinea); however, the examples are difficult to interpret. Semi-direct speech is not mentioned in her reference grammar of the language (MacDonald, 1990b). Logophoric pronouns in some Daghestanian languages occur in structures similar to semi-direct speech (cf. Kibrik, 1977, pp. 238; 316-317 on Archi; Kalinina, 2001, pp. 550-551; Ljutikova, 2001, pp. 652-658, on Bagvalal). 
form. The free pronoun within the speech report is a token of direct speech - it reflects what 'he' (the Original Speaker, different from the Current Speaker, 'me') had actually said:

Usan

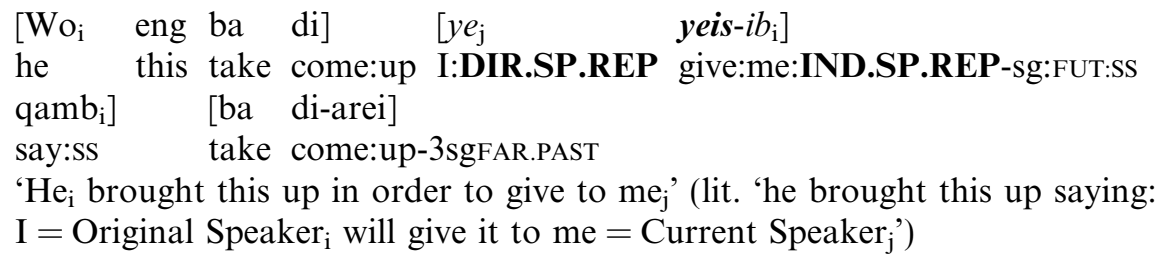

In (29), also from Usan (Reesink, 1987, pp. 258-259), the first person 'refers to a group of children of which the Current Speaker is a part, and the third person plural refers to the children's parents':

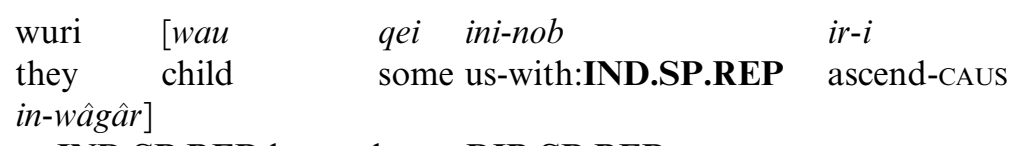

us:IND.SP.REP-leave.pl.IMPV:DIR.SP.REP

[qâmb] [maribig-umir

say.ss appoint-3persFAR.PAST

eng Boui

the Boui

ne Memind]

'They (parents) appointed Boui and Memind saying "May the children (that is, Boui and Memind) leave us (=a group which includes the Current Speaker)",

The token of indirect speech, 'us', is coreferential with the group which includes the Current Speaker (not the Original Speaker) and is expressed as an argument of a postposition, and also a bound pronoun on the verb. The token of direct speech is expressed in the imperative form of the verb itself.

Similar examples come from Lower Grand Valley Dani (Dani family, Papuan area: Bromley, 1981, p. 244). The Current Speaker, 'I', is the object of the speech report.

Lower Grand Valley Dani

(30) [n-asuwok]-olvk-at

me:IND.SP.REP-let's.kill.later:DIR.SP.REP-having.said-PREDICATE

ykhy-lakoukwha]

saying-they:were:FAR.PAST

'They used to make plans to kill me' (lit. They ${ }_{\mathrm{i}}$ (= Original Speaker) were saying having said 'Let's kill $\mathrm{me}_{\mathrm{j}}$ (= Current Speaker) later'

The token of indirect speech is coreferential with the Current Speaker, 'I', and is expressed as a bound pronoun on the verb. The token of direct speech is expressed in the imperative form of the verb 'kill' within the speech report.

In (31), from the same language, the Current Speaker, 'I', is the addressee within the direct speech report, and is cast as 'me' (rather than as 'him/her' or 'you' as was said in the original speech). The subject of the speech report is also 'I'. Both tokens of direct 
speech ('I') and of indirect speech reports ('me') are expressed as bound pronouns on the verb (Bromley, 1981, p. 245):

\author{
[wo'nesik-ylvk] \\ move-let.me.transfer.it.to.me:DIR.SP.IND.SP having.said.did.you(sg).say
}

'Did you $_{i}$ say that you ${ }_{i}$ were planning to give it to $\mathrm{me}_{\mathrm{j}}$ ?' (Lit. did you ( $_{\mathrm{i}}=$ Original speaker) say ' $\mathrm{I}_{\mathrm{i}}$ am planning to give (i.e. move.let.transfer) it to $\mathrm{me}_{\mathrm{j}}(=\mathrm{Current}$ Speaker)?')

In the descriptions of Usan and Lower Grand Valley Dani, semi-direct speech reports are presented as occasional alternatives to the usual direct speech reports. ${ }^{9}$ There is no information as to how semi-direct speech compares to direct speech, in terms of the use of vocatives, 'mimicking effect', pauses, or any other potentially criterial features (as was described for Manambu, in Table 4 above). The exact conditions under which semi-direct reports are preferred are equally unknown, and require further investigation for these languages. The feature they share is overt marking of the Current Speaker's role in a speech report quoted by them.

We can recall, from the discussion following Table 2, that speech report constructions with incomplete person shift such as *John said 'I $I_{\text {CurrentSpeaker }}$ saw Fred' or * $I_{\text {CurrentSpeaker }}$

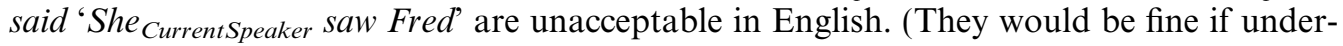
stood as indirect speech reports with the linker that omitted.) However, these constructions - analogous to the semi-direct speech attested in Papuan languages - do occur in imperative constructions.

Consider the following example, from colloquial British English. The Current Speaker is talking about an administrator who has told the Current Speaker to come and see him.

$\mathrm{I}_{\mathrm{CS}}$ rang up $\mathrm{Paul}_{\mathrm{i}}$, and $\mathrm{Paul}_{\mathrm{i}}$ said 'Come $\mathrm{CS}$ and see him,

What Paul had said was Come and see me (see (33a)). In the speech report construction in (32) the second person imperative form come is kept just as Paul might have uttered it. The Current Speaker ('I') is the addressee. This lack of shift of person is a token of direct speech. But the free pronominal form of the addressee, me, has been changed to him to fit in with the perspective of the Current Speaker. This is a token of indirect speech.

Straightforward direct and indirect speech report constructions corresponding to (32) are given in (33a) and (33b-c) respectively, for comparison. These are considered grammatical English, while the construction in (32) - albeit used - is rejected by many as an 'ungrammatical slip of the tongue'. ${ }^{10}$

\footnotetext{
${ }^{9}$ In Bromley's words, 'the person reference of any personal object-marking prefixes is interpreted from the standpoint of the speaker in all cases, so that in this construction, and only here, there occur verb forms which have first person object markers, referring to the speaker or the speaker with others, and also first person subject markers, where these refer to the addressee or any other non-speaker, since the marked subject person category is not interpreted from the standpoint of the speaker but of the subject of the superordinate verb' (1981, p. 244).

${ }^{10}$ I have recorded half-a-dozen instances of such uses, from native or near-native speakers of British and Australian English. No such examples have been located in the existing web-based corpora.
} 
(33a) I rang up Paul, and Paul said: 'Come and see me'

(33b) I rang Paul, and Paul said that I should come and see him

(33c) I rang Paul, and Paul told me to come and see him

(33d) I rang Paul, and Paul said to come and see him

The speech report in (32) shares another feature with direct speech reports - its 'theatrical effect'. As Clark and Gerrig (1990, p. 772) put it, quotations are 'demonstrations', and they often convey not just the words, but the intonation, the look, the gestures and so on; 'the internal structure of quotation is really the structure of what is being depicted, and that can range from the raging of a person to the racket of a machine'. In (33a) the Original Speaker mimicked the administrator's high-pitched voice and his broad Australian accent. This mimicking is perfectly possible with direct speech reports - as in (33a) but not with indirect speech - as in (33b) and (33c). Along similar lines, the administrator's high-pitched voice was mimicked in (32). This is a major reason why (32) cannot be considered an instance of indirect speech report with to omitted.

A similar example of a command directed at the Current Speaker and cast as a semidirect speech report is (34). The speaker had broken her contact lenses, the doctor was alarmed and told her to make an appointment as soon as possible. What the doctor actually had said was Make an appointment with me. The speaker reports this as:

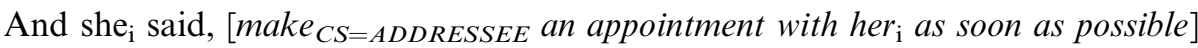

The speech report in (34) is similar to that in (32) in that the imperative form of the verb, make, is identical to what had actually been said and can be seen as a token of direct speech report. The free pronoun, her, has been changed to fit in with the perspective of the Current Speaker, and is a token of indirect speech.

A somewhat different example was recorded in the speech of a toddler. Sam was at the time 2 years 9 months old, and quite fluent for his age. His mother was trying to show us what he could say, and kept asking him: 'And what does Daddy say to you?' 'G'day, mate'. 'And what does Granny say to you?' 'Hello, dear'. 'And what does Mummy say to you? Sam, wash your hands?' To this last question Sam replied:

\section{Mummy says: 'Sam ${ }_{\mathrm{CS}}$, wash $_{C S=A D D R E S S E E} m y_{\mathrm{CS}}$ hands'}

Just like in (32) and (34), the imperative, wash, appears within the speech report in exactly the same form as Mummy had used it. It is a token of direct speech. But the possessive $m y$ is changed according to the perspective of Sam, the Current Speaker (rather than the Original Speaker's, Mummy), and is a token of indirect speech. ${ }^{11}$

All the instances in English which contain shift to the Current Speaker's perspective involve commands. Just like direct speech reports, these semi-direct speech constructions can contain vocatives, and mimic what has been said. The functions of these constructions and the pragmatic implications require further investigation. Examples (32), (34) and (35) illustrate that the inclusion of Current Speaker in speech report - resulting in the emergence of marginal semi-direct speech constructions - is a reality in everyday varieties of English.

We now turn to the few instances whereby semi-direct speech is obligatory.

\footnotetext{
${ }^{11}$ Note that Sam has never been a pronoun-reversing child (in the sense of Chiat, 1982, 1986; cf. Hanson, 2000): he did not used to employ 'I' instead of 'you' or 'you' instead of ' $I$ '. The relevance of 'semi-direct' speech for child language acquisition deserves further study.
} 


\subsection{Obligatory semi-direct speech}

Two languages, both from the New Guinea Highlands area, have been described as having semi-direct speech as an obligatory construction: Gahuku, from the Gorokan family (Deibler, 1971, 1976), and Dom, from the Chimbu family (Tida, 2006). ${ }^{12}$ Semi-direct speech is obligatory if the Current Speaker is first person and is also the addressee or the object within the speech report. In all other cases, direct speech is the only option.

Gahuku (Deibler, 1971, p. 115; 1976, pp. 110-118) is said to have just straightforward direct speech reports, in all but one context. If the speech report is made by first person subject who is also the addressee in the reported speech, the second or third person is shifted to first, to fit in with the perspective of 'I', the Current Speaker.

If (36) were a bona fide direct speech construction, we would have expected 'you' in lieu of 'me'. In (36), the Original Speaker had said 'We will seize your hands'. This appears in the speech report in (36) (Deibler, 1976, p. 115) as 'We will seize my hands'. The person reference of 'we' is determined by the perspective of the Original Speaker of 'we will seize your hands'. The person reference of 'my' is determined by the perspective of the Current Speaker.

The first person plural marker on the verb 'seize' within the speech report is a token of direct speech: this is exactly what the Original Speaker, 'you', had said. The first person singular in 'my hands' is coreferential with the Current Speaker and can be considered a token of indirect speech, since the person has 'shifted':

Gahuku

(36)

$\begin{array}{ll}{[\text { NIgizatoq }} & \text { al-it-UNE] } \\ \text { my.hands.at:IND.SP.RP } & \begin{array}{l}\text { take-FUT-1pl:DIR.SP.REP } \\ \text { niahe }]\end{array} \\ \text { [L-iki } & \text { are_you? }\end{array}$

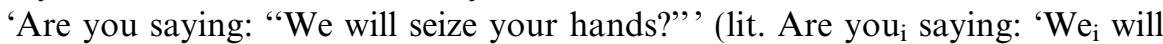
seize my $_{\mathrm{CS}}$ hands?')

In (37) (Deibler, 1971, p. 109), the third argument of the verb 'give' is coreferential with the Current Speaker, and its person reference is 'shifted' to the Current Speaker's perspective. What was said in the original speech report was 'I'll give it to you now'. The speech report within (37) is cast as 'I'll give it to us (= Current Speaker) now'. 'I' remains as in the original speech report, and thus can be considered a token of a direct speech report. 'Us' includes the Current Speaker ('he') and retains his perspective. The Current Speaker is the addressee.

[Lelliq nemoqza], [mota limitove] ours is.but now I'll.give.to.us:DIR.SP.REP.IND.SP.REP after.he.said

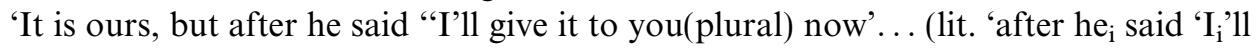

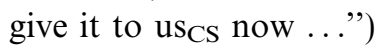

\footnotetext{
12 This construction was also described for Golin, a dialect of Dom (Loughnane, 2003, 2005). Tida, who produced a comprehensive grammar of the language based on several years of fieldwork in the Chimbu province (2006), provides a fuller account than Loughnane who was only able to work with one speaker in Melbourne during a limited period of time.
} 
In (38), the addressee of 'open' (Deibler, 1971, p. 110) is coreferential with the Current Speaker. A few further, similar examples are in Deibler (1976, p. 115).

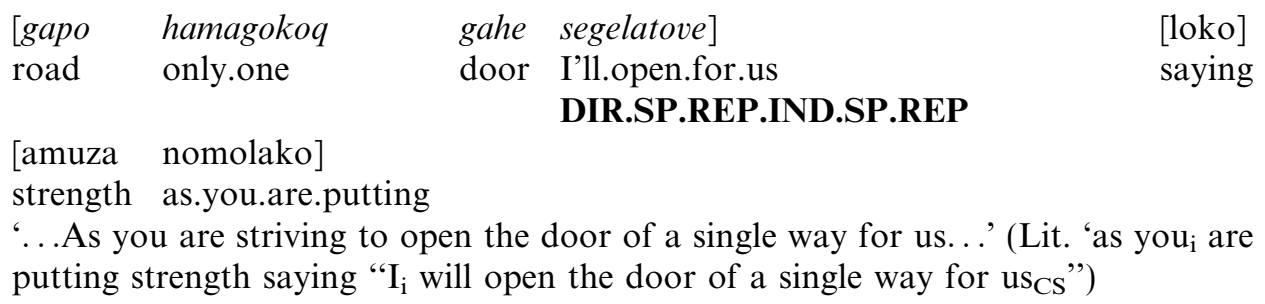

Along similar lines, in Dom (Tida, 2006, p. 219) semi-direct speech is obligatorily used when the Current Speaker is the object or the addressee of the speech report. In (39), the free pronoun is a token of direct speech report, and the bound pronoun ('me') is a token of indirect speech, from the perspective of the Current Speaker. The 'reporter' is expressed as a token of indirect speech - this is similar to Manambu.
$[-1 t a\lrcorner n a$
kar-Val]
$\dashv \mathrm{d} \quad$ /u-na-ga
a I(excl):DIR.SP.REP see-FUT.1sg:IND.SP.REP QUOT come-FUT-2sgsub

'(One) of you $\mathrm{i}_{\mathrm{i}}$ who would come (here) saying " $\mathrm{I}_{\mathrm{i}}$ will see him $\mathrm{CS}(=$ Current Speaker)" (lit. ' $\mathrm{I}_{\mathrm{i}}$ (=Original Speaker: IND.SP.REP) will see $\mathrm{me}_{\mathrm{CS}}(=$ Current Speaker:

DIR.SP.REP) $)^{, 13}$

In all other circumstances, straightforward direct speech reports are used. Note that, unlike other New Guinea languages mentioned here, Dom employs a special quotative marker to introduce any speech report.

\subsection{Parameters of variation in semi-direct speech reports}

Semi-direct speech reports can be an option; or they can be obligatory. They appear to coexist with direct and with indirect speech reports in just two languages where a semi-direct speech report is an optional choice: Manambu and Akosse. 'Original-Speaker-oriented' semi-direct speech of Type I has been attested in Manambu and Aksose. 'CurrentSpeaker-oriented' semi-direct speech of Type II has been attested in Usan, Lower Grand Valley Dani, Manambu, Gahuku, ${ }^{14}$ and Dom. Manambu differs from other languages discussed here in that it combines the two types of semi-direct speech. English has semi-direct speech constructions of Type II, limited to commands. Tokens of direct and indirect speech can be encoded by free pronouns, bound pronouns, or both. In Colloquial English, the imperative verb is a token of direct speech, and the free pronoun is a token of indirect speech.

The parameters of variation in semi-direct speech constructions of two types are summarized in Table 5.

\footnotetext{
$13 \dashv, \mathrm{V}, \wedge$ are tone marks (Tida, 2006).

14 In Deibler's (1971, p. 109) words, 'A verb-affix pronominal form in the quoted speech whose referent is the person or persons who are doing the quoting [that is, the speaker - A.A.] is a first-person pronoun instead of a second person as would have been used by the original speaker'.
} 
Table 5

Parameters of variation in semi-direct speech constructions

\begin{tabular}{|c|c|c|}
\hline \multicolumn{2}{|l|}{ Parameters for semi-direct speech } & Example languages \\
\hline \multicolumn{2}{|l|}{ Original-speaker-oriented: Type I } & Manambu, Akoose \\
\hline \multicolumn{2}{|l|}{ Current-speaker-oriented: Type II } & $\begin{array}{l}\text { Usan, Lower Grand Valley Dani, Colloquial English, } \\
\text { Gahuku, Dom }\end{array}$ \\
\hline \multirow[t]{2}{*}{ Obligatory or optional } & stylistic option & $\begin{array}{l}\text { Manambu, Aksose, Usan, Lower Grand Valley Dani, } \\
\text { Colloquial English }\end{array}$ \\
\hline & obligatory & Gahuku, Dom \\
\hline \multirow{2}{*}{$\begin{array}{l}\text { Existence of indirect speech as } \\
\text { a special speech report }\end{array}$} & yes & Manambu, Akoose, Colloquial English \\
\hline & no & Usan, Lower Grand Valley Dani, Gahuku, Dom \\
\hline \multirow{2}{*}{$\begin{array}{l}\text { Form of the token of } \\
\text { indirect speech }\end{array}$} & free pronoun & Manambu, Aksose, Dom, Colloquial English \\
\hline & bound pronoun & Lower Grand Valley Dani, Usan, Gahuku \\
\hline
\end{tabular}

The existence of Current-Speaker-oriented semi-direct speech constructions confirms the importance of the Current Speaker for a comprehensive typology of speech reports - despite the fact that for some languages, such as English (exemplified in Section 1.2), marking coreferentiality with the Current Speaker appears superfluous.

We will now compare the two types of semi-direct speech reports with instances which look superficially similar: 'mixed' speech reports, and the phenomenon of 'logophoricity'.

\subsection{Semi-direct speech and 'mixed' speech reports}

Semi-direct speech reports containing tokens of direct and indirect speech are reminiscent of 'mixed' direct and indirect speech (see Mittwoch, 1985, pp. 140-142; called 'mixed direct and indirect quotations' by Partee, 1973). Consider the following examples, all from written sources. Dixon describes how the Jamamadí people of Southern Amazonia came to be converted to Christianity by the Campbells, a missionary team (Dixon, forthcoming). The mixed direct and indirect speech is in bold.

(40) An intruding Branco had been shot by the Jamamadí at the end of the airstrip. But he was such an evil fellow that they really did fear his spirit. The Campbells said [that Jesus is all powerful] INDIRECT SPEECH REPORT and [only he can protect you - better convert double quick! $\left.\right|_{\text {DIRECT SPEECH REPORT' }}$

The direct speech report here is unlikely to be a verbatim quotation, but it has all the trappings of direct speech: lack of person shift and imperative form. Some authors put direct speech report inserts within quotes, as in (41) (Mittwoch, 1985, p. 140) and (42) (Weekend Australian Magazine, March 17-18, 2007, p. 14):

(41) $\mathrm{He}_{\mathrm{i}}$ assures the reader that during the journey he $\mathrm{i}_{\mathrm{i}}$ wrote down 'in the evening what during the day $I_{i}$ had seen...'

(42) Noxon started doing his research 'in order to understand myself'.

Such 'mixed' constructions are used to achieve a stylistic effect - making the narrative more vivid. These occur predominantly in written style. Unlike semi-direct speech of Type 
I described above, the identity between the Original Speaker and a participant within the speech report is optional. Unlike semi-direct speech reports of Type II, the Current Speaker's perspective is irrelevant.

\subsection{Semi-direct speech and logophoricity}

The phenomenon of logophoricity (identified in numerous African languages, and first introduced by Hagège, 1974) involves a special set of forms reserved for indirect speech clauses. They indicate that one of the referents of the embedded speech clause (often, but not always, the subject) is coreferential with one of the participants in the reporting ('matrix') clause. That is, examples such as (2a) and (2b) from English would be explicitly differentiated by different forms of 'he' - one coreferential with the Original Speaker, as in (2a), and one not, as in (2b).

Consider logophoric pronouns in Donno So, a Dogon language from Burkina Faso (Culy, 1994a) (underlined). In (43), the referent of 'he' is neither Anta nor Oumar. In (44) 'he' is Oumar. ${ }^{15}$

\section{Donno So}

(43) Oumar [Anta wo-ñ waa be] gi

Oumar Anta 3sg-OBJ seen AUX said

'Oumar ${ }_{i}$ said that Anta had seen him $_{k}$ '

(44) Oumar [Anta inyeme-ñ waa be] gi

Oumar Anta LOG-OBJ seen AUX said

'Oumar ${ }_{i}$ said that Anta had seen him $_{\mathrm{i}}$ '

As pointed out by Wiesemann (1990, pp. 78-79), logophoric reference is primarily employed in a situation where 'third person identification refers to any participant other than the speaker of the original speech act'. The instances of semi-direct speech of Type I and Type II discussed above do not - and cannot - serve the function of differentiating referents. They mark coreferentiality of a participant within the speech report with the Original Speaker, or with the Current Speaker. Note that current-speaker-oriented semi-direct speech differs from 'classical' logophoricity - which concerns a third-person speaker and a participant within the speech report - in that it includes marking of the Current Speaker.

An additional difference between semi-direct speech of Type II and logophoricity lies in the syntactic functions of the speech report participant coreferential (or not) with the Original Speaker. Logophoric pronouns are typically tied to the function of subject, or object. In contrast, reference to 'Current Speaker' in optional semi-direct speech of Type II spans a variety of participants ( $\mathrm{O}$ in (24) from Manambu, in (30) from Lower Grand Valley Dani and in (39) from Dom; addressee in (28) from Usan, (31) from Lower Grand Valley Dani and (32) from English; possessor in (35) from English).

\footnotetext{
${ }^{15}$ Alternatively, logophoricity can be expressed with verbal cross-referencing, or with a clitic (see Hyman and Comrie, 1981, p. 24; and an overview by Curnow, 2002a,b). This phenomenon is not confined to Africa (see LaPolla, 2003, p. 50 on a logophoric pronoun in Qiang, a Tibeto-Burman language; a so-called conjunct-disjunct person marking in Tibeto-Burman and Barbacoan languages has essentially the same function: Aikhenvald, 2004, pp. 133-134).
} 
Obligatory semi-direct speech of Type II is closer to logophoricity in that the Current Speaker has to be in the addressee or direct object function within the speech report (see (36)-(38) from Gahuku; and (39) from Dom). That is, semi-direct speech can be seen as a marker of coreferentiality between the Current Speaker and a particular participant within the speech report.

\subsection{Semi-direct speech and 'first-person logophoricity'}

An analogy can be drawn between semi-direct speech of Type II and so-called 'first person logophoricity'. In some African languages with logophoric pronouns, if the Original Speaker is the subject of the speech report, first person marking may appear in the speech report. This is illustrated with (45), also from Donno So (Culy, 1994b, p. 123). The person of the possessor is cast as if it were an indirect speech report (with a logophoric pronoun indicating the identity of Oumar and 'he', the possessor). First person marking on the verb is coreferential with the Original Speaker, Oumar, and reflects what one would expect in a direct speech report.

Oumar $\left[\begin{array}{llll}\{\text { minne } & \text { inyem } \varepsilon\} & \text { mo } & \text { gendezem }\end{array}\right]$ gi Oumar field LOG:IND.SP.REP POsS regard:PROG:1sg:DIR.SP.REP said

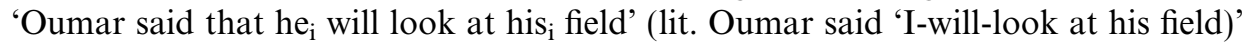

This 'first person logophoricity' (Curnow, 2002b, pp. 3-5) serves the same function as a logophoric pronoun - it indicates that an argument (often subject, but sometimes also an object) within a speech report is coreferential with the Original Speaker. It is indeed reminiscent of Type I of semi-direct speech. ${ }^{16}$

A similar instance of first person-only logophoricity has been documented for Central and East Hokkaido dialects of Ainu (Bugaeva, forthcoming, Section 2.3). If the Original Speaker is identical to the subject of the direct speech report, the inclusive pronoun 'I and you' is used, rather than the singular pronoun. The verb appears in the plural form:

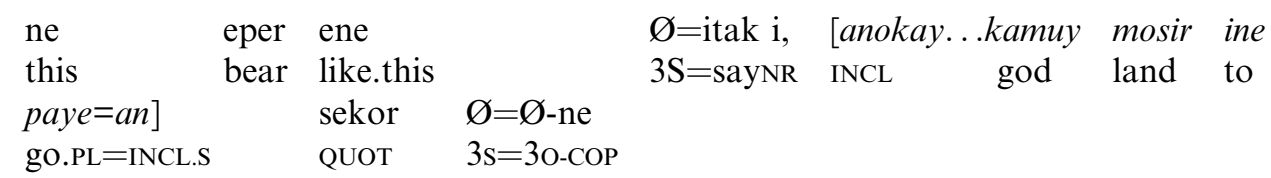

"The bear said: "I shall go to the land of gods (=die)", (lit. The bear said: "We (I+you + s/he/they) shall go to the land of gods")

This is comparable to what Wiesemann (1990, p. 78) refers to as 'direct reporting of the use of third person to refer to first or second person as a manner of speaking, such as [...] Somebody is hungry around here meaning 'I am hungry' Somebody has not finished his work meaning "you didn't finish". The difference lies in the fact that in examples like (46) from Ainu the inclusive pronoun is an obligatory choice and not a stylistic option.

There is thus a superficial similarity between first-person logophoricity in (45)-(46) and the semi-direct speech of Type I. But there are also two major differences.

\footnotetext{
16 This is also reminiscent of conjunct-disjunct person marking (see Curnow, 2002c; Hale, 1980; and the summary in Aikhenvald, 2004, pp. 123-128).
} 
Firstly, semi-direct speech of Type I is optional - in all the instances surveyed it is a stylistic option used to mark the Original Speaker's involvement in the event (see Section 2.3.2, for Manambu).

Secondly, the choice of a logophoric pronoun correlates with a syntactic function of the participant within the speech report coreferential with the Original Speaker (that is, the choice of a logophoric pronoun is determined by whether it is the subject or the object). In contrast, in languages with semi-direct speech of Type I the Original Speaker can have a plethora of syntactic functions within a speech report, including:

(i) $\mathrm{S}$ (intransitive subject), as in (18), from Manambu;

(ii) $\mathrm{O}$, as in (27), from Aksose, and (22), from Manambu; and

(iii) possessor, as in (20), from Manambu.

In addition, as can be seen from the analysis of Manambu (Section 2.3.1), semi-direct speech can be considered a separate speech report which shares some features with direct, and some with indirect speech. Semi-direct speech of Type I is a means of marking the Original Speaker's involvement. For languages with logophoricity this has been described as an obligatory mechanism, which has no such discourse functions. Whether or not once semi-direct speech becomes obligatory, it acquires additional, logophoric, functions remains an open question. ${ }^{17}$

\section{To conclude}

A major difference between direct and indirect speech lies in the way the person of the author of the original speech is cast. In direct speech, the person is expressed exactly as it was in the original speech report. In indirect speech, the person reference is shifted to the perspective of the Current Speaker. There is a third option - a 'middle ground' situation known as 'semi-direct' speech - with incomplete person shift.

Speech report constructions with incomplete person shift can be of two types. Type I, which tends to be optional, indicates the involvement of the Original Speaker in the speech report. There appear to be hardly any restrictions on the syntactic functions of the participant - coreferential with the Original Speaker - within the speech report: this is what distinguishes semi-direct speech from classical logophoric constructions.

Type II, which may be optional or obligatory, indicates coreferentiality of the Current Speaker - rather than the Original Speaker - with a participant within the speech report. This brings an additional dimension to the typology of speech report constructions: the necessity of including the perspective of Current Speaker as a parameter for classification and analysis of speech reports. Such constructions occur in English - albeit marginally (in English they are restricted to commands).

Semi-direct speech of Type II may be compared to first-person logophoricity, in that the two do a similar job, but with respect to different participants. While logophoricity indicates that an argument within a speech report is coreferential with the Original

\footnotetext{
17 Semi-direct speech reports may be obligatory under additional circumstances, independently of person value of the reporter. Slave (Athabaskan: Rice, 1986, 1989, pp. 1273-1289) has a class of 'direct discourse determining verbs' reminiscent of semi-direct speech: with these, 'Simon says that you hit him' translates as 'Simon says you hit me'.
} 
Speaker, semi-direct speech of Type II indicates that an argument within a speech report is coreferential with the Current Speaker.

The Manambu data are particularly instructive: they indicate that optional semi-direct speech reports of Type I and Type II may be significantly different from both direct and indirect speech. Semi-direct speech in this language can be considered a strategy for marking Original Speaker's, or Current Speaker's, involvement in a situation which affects them.

To what extent this also applies to other languages with optional semi-direct speech constructions remains an open question. Most languages with optional semi-direct speech have just direct speech reports. The existing grammars provide no information on how semi-direct speech compares to direct speech in terms of the potential 'mimicking' effect, semantic extensions not directly presupposing a speech event, and further properties.

A further question relates to the development and spread of semi-direct speech constructions. Like many other categories, speech report constructions are easily diffused. Logophoricity is an areal, rather than a genetic, property spread across unrelated African languages (as demonstrated by Güldemann, 2001, 2002, 2003; see Frajzyngier, 1985 on Chadic languages). Further examples of areally diffused speech reports abound. The emergence of indirect speech reports in Maale is the result of influence from Amharic; traditional Maale has only direct speech report constructions (Amha, 2001, pp. 199-200). In Evenki, clauses with indirect speech reports had to be nominalized; under Russian influence, Evenki allows the use of verbal indicative forms in indirect speech (Nedjalkov, 1997, pp. 1-3). And Modern Goemai has developed direct speech reports under influence from Hausa (Hellwig, forthcoming).

Both Gahuku and languages of the Chimbu family (which include Dom and Golin), where semi-direct speech of Type II is obligatory, are spoken in the New Guinea Highlands. Does this shared feature reflect a diffusional pattern? And can shared semi-direct speech patterns in Manambu (from the Sepik area), Lower Grand Valley Dani (spoken further west in West Papua), and Usan (spoken in Madang Province, bordering on the Sepik area) be attributed to a contact-induced change? These questions remain open until further studies become available.

\section{Acknowledgements}

I am grateful to those speakers of British and Australian English who allowed me to quote their informal speech (Simon Tully, Rowena Dixon, Siew-Peng Condon, Sam Trustram and Simon Trustram), and to the members of my adopted family in the village of Avatip (East Sepik, Papua New Guinea) who taught me their native Manambu, especially Jacklyn Yuamali Benji Ala and Pauline Yuaneng Luma Laki. I am grateful to R.M.W. Dixon, Anna Bugaeva, Jessica Cleary-Kemp, Carol Genetti, Rebecca Hanson, Gerd Jendraschek, Tida Syuntarô, Michael Daniel and the anonymous referees, for comments and suggestions.

\section{Appendix A. Distinguishing direct and indirect speech reports in cross-linguistic perspective}

'Direct' and 'indirect' speech reports differ in a variety of ways, including the expression of tense, intonation patterns, syntactic function of the speech report and many more. Speech report constructions can be multiclausal or monoclausal. 
Monoclausal speech reports can be of three kinds: (a) construction with a reported or a quotative evidential (see a brief overview in Aikhenvald, 2004, pp. 68-85); (b) construction with double person marking (as in Kwaza: van der Voort, 2000, pp. 291-296); and (c) free indirect discourse (see Quirk et al., 1985; Landeweerd and Vet, 1996, for French). Monoclausal speech reports often originate from reanalysis of multiclausal reports (see discussion in Aikhenvald, 2004, pp. 68-85, and Travis, 2006). Interactions between these and further intermediate phenomena are discussed at some length in Aikhenvald (forthcoming).

Within a multiclausal construction, a reporting marker can be a verb of speech, an expression 'be like' or 'do like' (see Romaine and Lange, 1998), or a combination of both. An intonation break, a pause, or a complementizer, typically mark the link between the reporting marker and the speech report.

Most languages of the world distinguish two multiclausal speech report constructions: direct and indirect speech. Direct speech (also called quote clause; or quote content) lacks the adjustment of personal, temporal and spatial deixis to the Original Speaker's perspective. It is expected to have all, or most, properties of a main clause. An indirect speech report is typically a kind of embedded complement clause.

Direct speech aims at close, if not fully verbatim, reproduction, of what has been said; 'direct discourse is "show" as well as speech, indirect discourse is speech only' (Wierzbicka, 1974, p. 272; and also see Partee, 1973). This is the basis for functional differences between direct and indirect speech. A quote can be of more than one clause; or it can consist of just one word, or one morpheme, or not contain any speech as such - just a gesture (Partee, 1973). See Li (1986, pp. 30-31) and Partee (1973), on the rejection of an earlier transformationalist claim that all indirect speech should be derived from direct speech. Further discussion on how to differentiate between direct and indirect speech reports can be found in Coulmas (1986), Güldemann (2001), and Güldemann and von Roncador (2002).

The distinguishing features of direct and indirect speech are discussed as follows

(i) Shift In PERSOnAl DeIXIs, to fit in with the perspective of the Original Speaker is a major defining property of indirect speech report constructions (see Section 1.1 above). An indirect speech report construction may require a simple person shift in pronouns as in (2a) where the original 'I' of the direct speech (in (1a)) has been shifted to 'he'. A language can employ logophoric (see Section 3.5 above), reflexive or emphatic pronouns for marking coreference between the subject of the reporting clause and the subject of the indirect speech report (Culy, 1994a, p. 1055; Carlson, 1994, pp. 444-445 on Supyire). ${ }^{18}$

Person shift is the most prominent feature for distinguishing direct and indirect speech. All other features can be considered concomitant to it.

(ii) Shift in SPATIAL AND In TEMPORAL DEIXIS.

Indirect speech report constructions may also involve change in SPATIAL DEIXIS. In Lango (Noonan, 1992, p. 227), the direct speech report in (47) employs a proximal locative 'here'. If the statement is framed as indirect speech, the deictic changes: what was 'here' for the author of the speech report, is 'there' for the Current Speaker in (48).

\footnotetext{
${ }^{18}$ See further references and discussion in Güldemann (2003), Dimmendaal (2001).
} 
Lango
(47) òkòbò
nî
[àkétò
pàlà kân]
3 sg+say+PERF COMPL $1 \mathrm{sg}+$ put + PERF knife here
'He said, "I put the knife here",

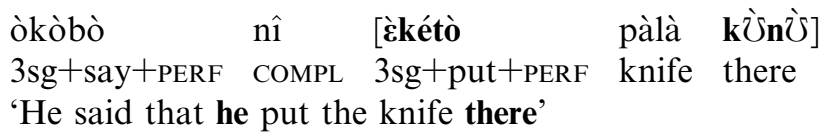

In English, an indirect speech report requires changing a time adverb - as in $(2 \mathrm{a}, \mathrm{b})$ above - and also spatial and other deictics, to fit in with the perspective of the Current Speaker. 'Here' and 'this' in direct speech (49) become 'there' and 'that' in an indirect speech report, and 'come' becomes 'go' $(50 \mathrm{a}, \mathrm{b})$, due to a switch in the 'deictic orientation' from that of the Original Speaker ('John' in (49)), to that of the Current Speaker (Li, 1986; Wiesemann, 1990). The Current Speaker's perspective may be different from that in the speech report content, as in $(50 \mathrm{a}, \mathrm{b})$. (50a) and (50b) are alternatives (see further discussion in Leech and Svartvik, 1975, pp. 149-150).

(49) John told Paul, 'Come here and take care of this mess'

(50a) John told Paul to go there and take care of that mess

(50b) John told Paul that he should go there and take care of that mess

In English - but not in Lango and many more languages - what was past in a direct quote changes to 'past in the past' in indirect speech as shown in (2a,b) above and (48). Such rules of TENSE SHIFT, also known as back-shifting, are prominent in many European languages. (Dixon, 2005, pp. 223-225 gives an instructive outline of the rules of back-shifting in English. An overview of back-shift in other European languages is in Janssen and van der Wurff, 1996b; also see Sakita, 2002 on how these rules apply in spoken English, and Sulkala and Karjalainen, 1992, p. 2, on Finnish).

Indirect speech can be marked with a special verb form: this is how conditional (Konjunktiv) is used in German and jussive in Estonian (ten Cate, 1996, p. 202; Erelt, 2002). Or the meaning of tenses may be different in indirect speech reports, and in direct speech reports and main clauses. In Finnish, the present tense in indirect speech may indicate that the action is continuous. In Rumanian (Malinson, 1986, p. 3), the use of conditional in indirect speech implies no responsibility for the truth of the report ('say that V-indicative' means 'say that V' and 'say that V-conditional' means 'allege that V'); no such connotations are found elsewhere in the language.

(iii) SPecial MARKIng of RePORTED COMmAnds. The occurrence of IMPERATIVE is likely to be restricted to direct speech and main clauses in general, and an alternative construction used in indirect speech: (49) and (50a, b) show how a to-infinitive and a that + should construction in indirect speech replace an imperative in direct speech (also see McGregor, 1994, p. 73). In Hdi (Frajzyngier, 2002, p. 451) a simple verb form in the indirect speech report corresponds to the imperative in the direct speech report; and in Finnish conditional is used in reported commands. In Taba (Western Austronesian: Bowden, 2001, pp. 390-391), the equivalent of an imperative in direct speech reports is a resultative form of the verb. It is not uncommon to employ a different construction type for an indirect speech report of a statement and of a command, as is the case in English, and in Gulf Ara- 
bic (here a complementizer marks an indirect speech report unless it is a reported command - then it is omitted: Holes, 1990, p. 2).

(iv) REPORTED QUESTIONS ('indirect questions') may take special complementizers when they occur in indirect speech reports (such as whether or if in English and their equivalents in Taba). There may be differences in constituent orders - a question in a main clause and in a direct speech report in English requires the inversion of subject and verb, while no such inversion is required if a question occurs in indirect speech. No tag questions occur in indirect speech in English (Quirk et al., 1985, p. 1032).

(v) OVERT MARKER OF SYNTACTIC LINK between the reporting expression and the speech report may be required for indirect speech, but not for direct speech. In (2a,b), from English, the optional COMPLEMENTIZER that differentiates statements in indirect speech from direct speech. All types of complement clause in English can mark indirect speech, in line with the fact that, cross-linguistically, indirect speech reports are often a subtype of complement clause (Dixon, 2005). In Manambu (see Table 3), a speech introducer may occur with direct speech reports, but not with indirect ones.

A complementizer may be used with both direct and indirect speech reports in Lango (see (47) and (48) above), Nkore-Kiga (Bantu: Taylor, 1985, p. 5), Lele (Frajzyngier, 2001, p. 374) and Koromfe (Rennison, 1997). Or neither can include a complementizer of any sort, as in Gooniyandi and Taba (McGregor, 1994; Bowden, 2001, pp. 390-391). In Ndyuka, a complementizer is equally optional with both (Huttar and Huttar, 1994, pp. 1-3).

If both direct and indirect speech reports occur with a complementizer, the difference between the two may lie in its frequency. In Supyire a complementizer is rarer with direct speech than with indirect speech (Carlson, 1994, p. 447), while in Tikar (Jackson, 1987, p. 100 ) it is the other way round. And in Ainu (Bugaeva, forthcoming; Tamura, 2000) different complementizers are used with direct, and with indirect speech reports. This takes us to our next point:

(vi) Presence and type of Reporting Verb or marker often differentiates direct and indirect speech reports. A direct speech report - but not indirect speech - may occur without a framing clause of speech, as in Modern Hebrew (Zuckermann, 2006), Gooniyandi, Tuvaluan (Besnier, 2000, p. 3), Paumarí (Chapman and Derbyshire, 1991, pp. 242-243) and Urubu-Kaapor (Kakumasu, 1986, p. 338). In Maori, many more verbs of speech introduce indirect reports than direct reports (Bauer et al., 1993, p. 1). In Ainu, it is the opposite (Bugaeva, forthcoming). In many cases if a verb can occur with a direct speech report it can occur with an indirect one. There are exceptions - in colloquial English go and (be) like only occur with direct speech reports (see Buchstaller, 2005, 2006 on their functions, and attitudes to them in modern British and American Englishes). Modern Hebrew employs the verb 'do' as a marker of direct speech reports (Zuckermann, 2006, p. 475). Verbs which do not normally refer to speech acts often introduce direct speech reports (but are not employed for indirect speech); examples include Vinitiri (Oceanic, Austronesian: Van Der Mark, 2007) lari 'be like', Aguaruna (Jivaroan: Overall, 2007) wahát 'stop; call' and Dyirbal (Australian: Dixon, 1972, p.c.) yalama-y/l 'do like this'; also see Golato (2000) on so 'so' as a speech report introducer in colloquial German.

(vii) Position of THE SPEECH REPORT IN THE SENTENCE differentiates direct and indirect speech reports in Evenki (Nedjalkov, 1997, pp. 1-3) where indirect speech reports follow the reporting verb while direct speech reports may follow or precede it. Direct speech in Awtuw (Feldman, 1986, pp. 160-161, 169) follows a speech verb preceded by an adverb meaning 'thus', and indirect speech reports can occur clause-medially. And in Turkish 
(Kornfilt, 1997, p. 3) indirect speech reports may occur anywhere in the sentence, while direct speech reports may occur only to the immediate left of the report verb 'say'. In Gooniyandi the reporting marker may precede or follow a direct speech report, and always precedes an indirect speech report.

This is directly linked to:

(viii) SPECIFIC CONSTITUENT ORDER WITHIN THE SENTENCE WITH SPEECH REPORT. In Russian (a language with relatively free constituent order), if a direct speech complement precedes the reporting verb, the subject obligatorily follows the verb (see Clarke, 2005, and further references there; and Malinson, 1986, pp. 1-2, for a similar tendency in Rumanian). The direct speech report in English can be placed before or after the reporting clause - as shown in (51). The reporting clause may interrupt the speech report. This is characteristic of the written language (but not so much of the spoken language).

$$
\begin{aligned}
& \text { 'Please,' John said, 'don't do this' } \\
& \text { 'Please,' said John, 'don't do this' } \\
& \text { John said, 'Please, don't do this' } \\
& \text { 'Please, don't do this,' said John } \\
& \text { 'Please, don't do this,' John said } \\
& \text { Said John, 'Please, don't do this' }
\end{aligned}
$$

The subject in a direct speech report is often placed after the reporting verb - unless it is a personal pronoun:

'I need more money,' $\left\{\begin{array}{l}\text { John exclaimed } \\ \text { exclaimed John } \\ \text { he exclaimed }\end{array}\right.$ *exclaimed he (Leech and Svartvik, 1975, p. 117)

The starred option would have been fine if the verb of speech were say: 'I need more money,' said he.

(ix) Special intonation contour for direct speech report - different from that of an independent clause and an indirect report - has been described for Maltese (Borg and Azzopardi-Alexander, 1997, pp. 1-3) and Cairene Egyptian Colloquial Arabic (Gary and Gamal-Eldin, 1984, p. 3). ${ }^{19}$ A sentence containing a direct speech report in Modern Greek has an intonational break before the start of the direct speech itself, unlike other sentence types including indirect speech (Joseph and Philippaki-Warburton, 1987, p. 3).

(x) Vocatives and exclamations occur only in direct speech reports, and not in indirect speech in most languages. ${ }^{20}$ This is in line with 'mimetic', or 'theatrical' character of direct speech reports pointed out by Clark and Gerrig (1990), and by Wierzbicka (1974).

FURTHER MARKERS OF DIRECT SPEECH REPORTS include the use of quotative or reported evidentials. An evidential particle in Tamil occurs only with direct speech reports (Asher, 1985, pp. 1-3). In Japanese both direct and indirect speech reports can contain one of several quotative particles; according to Hinds (1986, pp. 4-5), only in indirect speech may a quotative particle be replaced by a qualifying phrase, meaning 'something like' or 'like'. In many

\footnotetext{
19 Similar examples are Nunggubuyu (Heath, 1984, p. 559), Tuvaluan (Besnier, 2000, p. 5), Ndyuka (Huttar and Huttar, 1994, p. 7) and Maybrat (Dol, 1999, pp. 222-223).

${ }^{20}$ Further similar examples include Korean, Finnish, Nunggubuyu and Tuvaluan (Sohn, 1994, p. 13; Sulkala and Karjalainen, 1992, p. 1; Heath, 1984, p. 559; Besnier, 2000, p. 5).
} 
languages the direct - but not the indirect - speech report may be discontinuous: this applies to English, Modern Hebrew (Zuckermann, 2006), Gooniyandi and Ungarinjin (McGregor, 1994, p. 74; Rumsey, 1982, p. 164). ${ }^{21}$ This property is far from universal: Colloquial Russian (Clarke, 2005, p. 380) allows both direct and indirect speech reports to be discontinuous.

There may be further, language specific, differences between direct and indirect speech. In Korean, honorific forms are typical of independent clauses and direct speech reports; in indirect speech they are replaced with neutral forms (Sohn, 1994, p. 11). In Hungarian (Kiefer, 1986), if the verb 'say' takes the headless proximal demonstrative $e z$ as its object, it can only be followed by a direct speech report. In contrast, the distal demonstrative in the same function requires an indirect speech report introduced by the complementizer hogy 'that, how'. Direct speech reports in Awtuw cannot take case-marking - unlike indirect speech reports (Feldman, 1986). And we saw in Section 2.2.2 that indirect speech reports in Manambu are never introduced with a cataphoric ata 'thus', while direct speech reports always are.

We saw in (iii) and (iv) above that speech act distinctions (commands, and questions) appear in direct speech reports just as in any other main clause. In contrast, when used in indirect speech reports, both commands and questions are often replaced with other clause types. We saw in Section 2.2.2 that in some languages reported commands are the only instance of indirect speech.

And last, but not least: an indirect speech report is typically a full clause, while a direct speech report may be less than a clause, or may consist of several sentences. ${ }^{22}$

So far, we have identified a number of properties which should allow us to unambiguously distinguish between the two varieties of speech reports.

This distinction is irrelevant for those languages which have just one multiclausal speech report construction - a direct speech report. This is the case in numerous Australian languages, e.g. Dyirbal, Ngalakan (Merlan, 1983, pp. 151-152) and Mangarayi (Merlan, 1982, pp. 1-4), and also many Amazonian languages (e.g. Urubu-Kaapor (Tupí-Guaraní: Kakumasu, 1986), Matses (Panoan: Fleck, forthcoming), in Chamling (Tibeto-Burman) and Nepali (Indic) (Ebert, 1986)). Then the direct speech report accompanies the verb of speech which can precede or follow it, depending on the language. A direct speech report can be accompanied by the quotative evidential in Kombai (de Vries, 1990) and a number of Uto-Aztecan languages (Munro, 1978).

And in some languages indirect speech reports are employed only for certain clause types (reported commands), while direct speech reports are predominant in others. This is the case in Manambu - see Section 2.2 above.

But are 'direct' and 'indirect' speech reports always clear-cut? The answer is 'no'.

Direct speech reports often vary as to how 'faithful' to the original they are. This takes us to a potential difference between direct quotation and direct speech reports. Let's take a couple of naturally occurring examples (with names changed). On a Saturday, John said: 'I

\footnotetext{
${ }^{21}$ If a direct speech report can be discontinuous, can it be placed between any constituents, or between parts of one phrasal constituent? This requires further study.

22 Direct and indirect speech reports can also differ in terms of their syntactic status. Indirect speech reports are usually a type of complement clause, while direct speech reports may share similarities with complement clauses (see, for instance, Genetti, 2006), but may have a special syntactic status (further discussion is in Aikhenvald, forthcoming).
} 
will go to Sorrento on Friday'. On this same Saturday, his girlfriend repeated what he'd said, quoting him verbatim:

'John said, "I will go to Sorrento on Friday",

When Thursday came, she repeated what John had said as (54), readjusting the time word to her perspective:

'John said, "I will go to Sorrento tomorrow",

This is not exactly what John had said - his words have been slightly rephrased to agree with the Current Speaker's time perspective. Yet this is still a direct speech report: there is no person shift, and no back-shifting of tense.

An even clearer differentiation between quotations and direct speech reports has been described for Athabaskan languages. Different speech-reporting verbs are used depending on whether the speech report is (i) direct quotation whereby speech is quoted verbatim; (ii) direct discourse whereby some deictic markers - e.g. time - can be shifted, or (iii) indirect discourse, with the shift of all the relevant deictic markers (see Schauber, 1979, pp. 19-29, for Navajo; Saxton, 1998, for Dogrib).

And more often than not, a direct quote is a distilled version of what the person has actually said - hesitation marks or false starts (and sometimes grammatical errors) may be omitted or adjusted (also see Clark and Gerrig, 1990).

We can safely assert that in English, the direct speech report in (54) will be 'less direct' than in (53) - simply because the time word's reference has been shifted as one would expect in indirect speech, while other categories have not. To account for such intermediate cases, we suggest that the difference between speech reports, from verbatim quote to indirect speech, be considered as a continuum - shown in Fig. 1.

For each language, different 'cut-off' points have to be plotted separately on such a continuum, depending on how many grammatical features of indirect speech allow 'exceptions' (as in (54)) - that is, whether the shift of a deictic category is strictly obligatory, or less so. (See Saxton, 1998; Schauber, 1979, on grammatical differences between quotes and direct speech reports in Athabaskan languages).

Even with the continuum approach, 'direct speech' is not always easy to distinguish from 'indirect speech'. English has a variety of grammatical features distinguishing the two, including the rules of 'sequence of tenses', and shift of person and other deictic categories, all exemplified above. Nevertheless, the distinction between direct and indirect speech can get 'blurred' - see the discussion by Huddleston (2003, p. 1029). Compare direct speech in Tell Richard: "Fred's my best friend" with indirect speech in Tell Richard that Fred's my best friend (Quirk et al., 1985, p. 1023). If that is omitted, the resulting sentence Tell Richard Fred's my best friend becomes ambiguous. In the written text, both

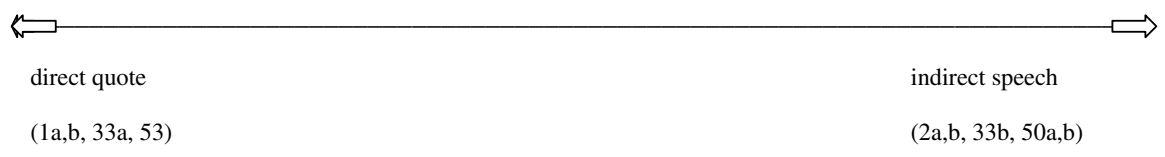

'direct speech report' (54)

Fig. 1. Speech reports as a continuum. 
direct and indirect speech interpretations are possible (the quotation marks make it clear). In the spoken language, the intonation may help, but only partly. In an isolating language, like Thai, with extensive ellipsis, difficulties in distinguishing direct and indirect speech may be even greater (Stephen Morey p.c.). Since there is no grammatical marking of person (and personal pronouns are frequently omitted), even 'person shift' is hard to rely upon as an ultimate criterion. Instances where no criterion is strictly applicable fall into a general category of speech reports of indeterminate type whose exact interpretation depends on the context.

\section{Appendix B. Points to be addressed when investigating speech reports in a language}

The following are among the main questions to be addressed when analyzing speech reports in a language. These will be of use to fieldworkers, working on previously undescribed or poorly described languages, and also to those scholars who are working on better-known languages.

(1) General properties of speech report constructions

What are the constructions employed for reporting speech? How many multiclausal and/or monoclausal speech report constructions does the language have?

If the language has a distinction between indirect and direct speech reports, what are their distinguishing features in terms of:

(i) shift in person deixis (with particular attention to coreference and disambiguation of third person referents);

(ii) shift in spatial and temporal deixis (and in tense on verbs);

(iii) changes in mood and modality;

(iv) report of commands (also known as indirect commands);

(v) report of questions (also known as indirect questions);

(vi) presence or absence of a complementizer.

Additional distinctions may include: intonational differences; different use of interjections and exclamations; differences in constituent order; differences in behaviour of demonstratives, and perhaps more.

Can a direct speech report be discontinuous? If so, are there any rules or tendencies as to how it is placed with respect to other constituents? Can it intervene between parts of a constituent? Can a direct speech report be longer or shorter than a clause?

Are there any instances of semi-direct speech (Type I, Original-Speaker-oriented, or Type II, Current-speaker-oriented)? How do semi-direct speech reports compare to speech reports of other kinds (direct and indirect)? Are semi-direct speech reports obligatory or optional?

What kind of monoclausal speech report construction does the language have (if any); frequent possibilities include an evidential, or free indirect speech.

(2) Syntactic role of speech report content

(2.1) Provide a statement of transitivity of reporting verb(s) and speech report constructions 
(2.2) If the language has indirect speech, is it similar to a complement clause, or is it a separate clause type? If the language does not have complement clauses as a special type, is another clause type, or complementation strategy, co-opted as a functional equivalent of indirect speech?

What is the syntactic status of direct speech? Can a speech report be questioned, or referred to with an anaphoric pronoun? What is the position of a reporting verb or a quote framer within the sentence?

(2.3) Are reporting verbs or quote framers obligatory? Which verbs or other, non-verbal, expressions, can be used as quote framers? How do they differ from each other? Can they differentiate direct and indirect speech constructions?

(3) Polysemous patterns for reporting verb and quote framers

Are speech report constructions used for the expression of reported thought, intention and/or purpose, wish, cognition and perception, dubious information, comparative or causative marker? Are speech report constructions obligatorily employed for introducing onomatopoeia?

(4) Can you say anything about the grammaticalization patterns of the reporting verb and of quote framer(s) and/or the speech report construction?

(5) Functional, stylistic and discourse implications of speech report constructions

If a language has a choice between several speech report constructions, what are the conditioning factors for the preferential choice of one over the other? For instance, are there any differences in degree of commitment to the veracity of the statement, or correlations with the person of the narrator, or information structure? Are direct or indirect speech reports, or any other speech report construction, a feature of any particular style (e.g. historical narrative)?

(6) Have any of the speech report constructions in the language been influenced by a neighbouring language, or have arisen as the result of areal diffusion and language contact?

\section{References}

Aikhenvald, Alexandra Y., 2004. Evidentiality. Oxford University Press, Oxford.

Aikhenvald, Alexandra Y., 2008. The Manambu language from East Sepik, Papua New Guinea. Oxford University Press, Oxford.

Aikhenvald, Alexandra Y., forthcoming. The Art of Grammar.

Amha, A., 2001. The Maale Language. Leiden University, Leiden.

Asher, R.E., 1985. Tamil. Croom Helm, London.

Bauer, W., Parker, W., Te Kareongawai, Evans, 1993. Maori. Routledge, London and New York.

Berry, K., Berry, C., 1999. A Description of Abun: A West Papuan Language of Irian Jaya. Pacific Linguistics, Canberra.

Besnier, N., 2000. Tuvaluan. Routledge, London.

Borg, A., Azzopardi-Alexander, M., 1997. Maltese. Routledge, London.

Borkovskij, V.I., Kuznetsov, P.S., 1965. Istoricheskaya grammatika russkogo jazyka. (Historical Grammar of the Russian Language). Nauka, Moscow.

Bowden, J., 2001. Taba. Description of a South Halmahera Language. Pacific Linguistics, Canberra.

Bromley, H.M., 1981. A Grammar of Lower Grand Valley Dani. Pacific Linguistics, Canberra. 
Buchstaller, Isabelle, 2005. Putting perception to the reality test: The case of go and like. University of Pennsylvania Working Papers in Linguistics 10.2, 61-76.

Buchstaller, Isabelle, 2006. Social stereotypes, personality traits and regional perception displaced: Attitudes towards the "new" quotatives in the UK. Journal of Sociolinguistics 10, 362-381.

Bugaeva, Anna, forthcoming. Direct and indirect speech in Ainu.

Carlson, R., 1994. A Grammar of Supyire. Mouton de Gruyter, Berlin.

Chapman, S., Derbyshire, D.C., 1991. Paumari. In: Derbyshire, D.C., Pullum, G.K. (Eds.), . In: Handbook of Amazonian languages, vol. 1. Mouton de Gruyter, Berlin, pp. 161-354.

Chiat, S., 1982. If I were you and you were me: The analysis of pronouns in a pronoun-reversing child. Journal of Child Language 9, 359-379.

Chiat, S., 1986. Personal pronouns. In: Fletcher, P., Garman, M. (Eds.), Language Acquisition. Cambridge University Press, Cambridge, pp. 339-355.

Clark, H.H., Gerrig, R.J., 1990. Quotations as demonstrations. Language 66, 764-805.

Clarke, Jonathan E.M., 2005. Speech report constructions in Russian. Acta Linguistica Hungarica 52, 367-381.

Coulmas, F. (Ed.), 1986. Direct and Indirect Speech. Mouton de Gruyter, Berlin.

Culy, C., 1994a. Aspects of logophoric marking. Linguistics 32, 1055-1094.

Culy, C., 1994b. A note on logophoricity in Dogon. Journal of African Languages and Linguistics 15, 113-125.

Curnow, Timothy J., 2002a. Three types of verbal logophoricity in African languages. Studies in African Linguistics $31,1-25$.

Curnow, Timothy J., 2002b. Verbal logophoricity in African languages. In: Collins, Peter, Amberber, Mengistu (Eds.), Proceedings of the 2002 Conference of the Australian Linguistic Society. http://www.als.asn.au.

Curnow, Timothy J., 2002c. Conjunct/disjunct marking in Awa Pit. Linguistics 40, 611-627.

Deibler, E.W., 1971. Uses of the verb 'to say' in Gahuku. Kivung 4, 101-110.

Deibler, E.W., 1976. Semantic relationships of Gahuku verbs. Summer Institute of Linguistics. Normal University of Oklahoma.

Dimmendaal, G.J., 2001. Logophoric marking and represented speech in African languages as evidential hedging strategies. Australian Journal of Linguistics 21, 131-157.

Dixon, R.M.W., 1972. The Dyirbal Language of North Queensland. Cambridge University Press, Cambridge.

Dixon, R.M.W., 2005. A Semantic Approach to English Grammar. Oxford University Press, Oxford.

Dixon, R.M.W., forthcoming. I am a linguist.

Dol, P., 1999. A grammar of Maybrat, a language of the Bird's Head, Irian Jaya, Indonesia. Leiden University, Leiden.

Drabbe, P., 1955. Spraakkunst van het Marind, Zuidkust Nederlands Nieuw-Guinea. Drukkerij Missiehuis St. Gabriël, Wien-Moedling.

Drabbe, P., 1957. Spraakkunst van het Aghu-dialect van de Awjutaal. Nijhoff, Den Haag.

Drabbe, P., 1959. Kaeti en Wambon, Twee Awju-dialecten. Nijhoff, Den Haag.

Ebert, K., 1986. Speech reporting in some languages of Nepal. In: Coulmas (1986), pp. 145-160.

Erelt, M., 2002. Does Estonian have the jussive? Linguistica Uralica 2, 110-117.

Faraclas, N.G., 1996. Nigerian Pidgin. Routledge, London and New York.

Feldman, H., 1986. A Grammar of Awtuw. Pacific Linguistics, Canberra.

Fennell, J., Obolensky, D., 1969. A Historical Russian Reader. A Selection of Texts from the XIth to the XVIth centuries. Clarendon Press, Oxford.

Fleck, David, forthcoming. A Grammar of Matses. Mouton de Gruyter, Berlin.

Frajzyngier, Z., 1985. Logophoric systems in Chadic. Journal of African Languages and Linguistics 7, $23-37$.

Frajzyngier, Z., 2001. A Grammar of Lele. CSLI Publications, Stanford.

Frajzyngier, Z., 2002. A Grammar of Hdi. Mouton de Gruyter, Berlin.

Gary, J.O., Gamal-Eldin, S., 1984. Cairene Egyptian Colloquial Arabic. Routledge, London.

Genetti, C., 2006. Complementation in Dolakha Newari. In: Dixon, R.M.W., Aikhenvald, Alexandra Y. (Eds.), Complementation. Oxford University Press, Oxford, pp. 137-158.

Golato, A., 2000. Und ich so / und er so [an I'm like / and he's like]: an innovative German quotative for reporting on embodied actions. Journal of Pragmatics 32, 29-54.

Grimes, Joseph E., 1975. The Thread of Discourse. Mouton, The Hague.

Güldemann, T., 2001. Quotative constructions in African languages: a synchronic and diachronic survey. Leipzig University, Habilitationsschrift.

Güldemann, T., 2002. When "say" is not say: the functional versatility of the Bantu quotative marker $t i$ with special reference to Shona. In: Güldemann and von Roncador (Eds.), pp. 253-288. 
Güldemann, T., 2003. Logophoricity in Africa: an attempt to explain and evaluate the significance of its modern distribution. Sprachtypologie und Universalienforschung 56, 366-387.

Güldemann, T., von Roncador, M. (Eds.), 2002. Reported Discourse. A Meeting Ground for Different Linguistic Domains. John Benjamins, Amsterdam.

Hagège, C., 1974. Les pronoms logophoriques. Bulletin de la Société de Linguistique de Paris 69, 287-310.

Hale, A., 1980. Person markers: finite conjunct and disjunct verb forms in Newari. In: Trail, R.L. (Ed.) Papers in South-East Asian Linguistics, No. 7, Pacific Linguistics, Canberra, pp. 95-106.

Hanson, Rebecca, 2000. Pronoun acquisition and the morphological feature geometry. In: Atkey, Susan, Curzon, Jana, Dobrovolsky, Michael (Eds.), Calgary Working Papers in Linguistics 22, Department of Linguistics, Calgary, pp. 1-14.

Heath, Jeffrey, 1984. Functional Grammar of Nunggubuyu. Australian Institute of Aboriginal Studies, Canberra.

Hedinger, Robert, 1981. The pronouns of Akosse. Studies in African Linguistics 12, 277-290.

Hedinger, Robert, 1984. Reported speech in Akoose. The Journal of West African Languages XIV, 81-102.

Hellwig, B., forthcoming. A grammar of Goemai (a West Chadic language of Nigeria).

Hellwig, B., 2006. Complementation in Goemai. In: Dixon, R.M.W., Aikhenvald, Alexandra Y. (Eds.), Complementation. Oxford University Press, Oxford, pp. 204-223.

Hill, H., 1995. Pronouns and reported speech in Adioukrou. The Journal of West African Languages XXV, 87106.

Hinds, J., 1986. Japanese. Croom Helm, London.

Holes, C., 1990. Gulf Arabic. Routledge, London and New York.

Huddleston, R., 2003. Content clauses and reported speech. In: Huddleston, R., Pullum, G.K. (Eds.), The Cambridge Grammar of the English Language. Cambridge University Press, Cambridge, pp. 947-1030.

Huttar, G., Huttar, M., 1994. Ndyuka. Routledge, London.

Hyman, L., 1978. The phonology and noun structure. In: Hyman, L.M. (Ed.), Aghem Grammatical Structure. Southern California Occasional Papers in Linguistics, no 7, University of Southern California, Los Angeles, pp. 1-72.

Hyman, L., Comrie, B., 1981. Logophoric reference in Gokana. Journal of African Languages and Linguistics 3, $19-37$.

Hyslop, C., 2001. The Lolovoli Dialect of the North-East Ambae Language, Vanuatu. Pacific Linguistics, Canberra.

Jackson, E., 1987. Direct and indirect speech in Tikar. Journal of West African Languages 17, 98-109.

Jakobson, R., 1990. Shifters, categories, and the Russian verb. Selected Writings. Word and Language. Mouton, The Hague, Paris, pp. 130-153.

Janssen, T.A.J.M., van der Wurff, W. (Eds.), 1996a. Reported Speech: Forms and Functions of the Verb. John Benjamins, Amsterdam.

Janssen, T.A.J.M., van der Wurff, W., 1996b. Introductory remarks on reported speech and thought. In: Janssen and van der Wurff, 1996a, pp. 1-14.

Joseph, B.D., Philippaki-Warburton, I., 1987. Modern Greek. Routledge, London and New York.

Kakumasu, J., 1986. Urubu-Kaapor. In: Derbyshire, D.C., Pullum, G.K. (Eds.), . In: Handbook of Amazonian Languages, vol. 1. Mouton de Gruyter, Berlin, pp. 326-403.

Kalinina, E.Yu., 2001. Aktantnye predlozhenija. In: Kibrik, A.E., Kazenin, K.I., Ljutikova, E.A., Tatevosov, S.G. (Eds.), Bagvalinskij jazyk. Grammatika. Teksty. Slovari. Nasledie, Moscow, pp. 512-553.

Kibrik, A.E., 1977. Opyt strukturnogo opisanija archinskogo jazyka. Tom II. Taksonomucheskaja grammatika. Izdateljstvo Moskovskogo Universiteta, Moscow.

Kiefer, F., 1986. Some semantic aspects of indirect speech in Hungarian. In: Coulmas (1986), pp. 201-218.

Klamer, M., 2000. How report verbs become quote markers and complementizers. Lingua 110, 69-98.

Kornfilt, J., 1997. Turkish. Routledge, London and New York.

Landeweerd, R., Co Vet, 1996. Tense in (free) indirect discourse in French. In: Janssen and van der Wurff, 1996a, pp. 141-162.

LaPolla, R., 2003. A Grammar of Qiang. Mouton de Gruyter, Berlin.

Leech, G., Svartvik, J., 1975. A Communicative Grammar of English. Longman, London.

Li, C., 1986. Direct and indirect speech: a functional study. In: Coulmas (1986), pp. 29-45.

Ljutikova, E.A., 2001. Anaforicheskie sredstva. In: Kibrik, A.E., Kazenin, K.I., Ljutikova, E.A., Tatevosov, S.G. (Eds.), Bagvalinskij jazyk. Grammatika. Teksty. Slovari. Nasledie, Moscow, pp. 615-681.

Loughnane, R., 2003. Reported speech in Golin (a Papuan language of New Guinea). Honours thesis. University of Melbourne. 
Loughnane, R., 2005. Reported speech constructions in Golin. In: Evans, Nicholas, Besold, Jutta, Stoakes, Hywel, Lee, Alan (Eds.), Materials on Golin. Grammar, Texts and Dictionary. Department of Linguistics and Applied Linguistics, The University of Melbourne, pp. 132-151.

MacDonald, L., 1990a. Evidentiality in Tauya. Language and Linguistics in Melanesia 21, 31-46.

MacDonald, L., 1990b. A Grammar of Tauya. Mouton de Gruyter, Berlin.

Malinson, G., 1986. Rumanian. Routledge, London.

Matthews, W.K., 1960. Russian Historical Grammar. Athlone, London.

McGregor, W., 1994. The grammar of reported speech and thought in Gooniyandi. Australian Journal of Linguistics 14, 63-92.

Merlan, F., 1982. Mangarayi. North Holland, Amsterdam.

Merlan, F., 1983. Ngalakan Grammar, Texts and Vocabulary. Pacific Linguistics, Canberra.

Mittwoch, Anita, 1985. Sentences, utterance boundaries, personal deixis and the E-hypothesis. Theoretical Linguistics 12, 137-152.

Munro, P., 1978. Chemehuevi "say" and the Uto-Aztecan quotative pattern. In: Donald, R. Tuohy (Ed.), Selected Papers from the 14th Great Basin Anthropological Conference. Ballena Press, Socorro, New Mexico, pp. 149-171.

Munro, P., 1982. On the transitivity of "say" verbs. Syntax and Semantics. In: Hopper, P.J., Thompson, S.A. (Eds.), . In: Studies in Transitivity, vol. 15. Harcourt Press, New York and London, pp. 301-319.

Nedjalkov, I., 1997. Evenki. Routledge, London and New York.

Noonan, M., 1992. A Grammar of Lango. Mouton de Gruyter, Berlin.

Noss, Philip A., 1988. Speech, structure and aesthetics in a Gbaya tale. Journal of West African Languages XVIII (1), 97-115.

Overall, Simon, 2007. A grammar of Aguaruna. Ph.D. dissertation, La Trobe University.

Partee, B.H., 1973. The syntax and semantics of quotation. In: Anderson, S., Kiparsky, P. (Eds.), A Festschrift for Morris Halle. Holt, Rinehart and Winston, New York, pp. 410-418.

Perrin, M., 1974. Direct and indirect speech in Mambila. Journal of Linguistics 10, $27-37$.

Post, Mark, 2007. A grammar of Galo. Ph.D. dissertation, La Trobe University.

Quirk, R., Greenbaum, S., Leech, G., Svartvik, J., 1985. A Comprehensive Grammar of the English Language. Longman, London.

Reesink, G.P., 1987. Structures and their Functions in Usan, a Papuan Language of Papua New Guinea. John Benjamins, Amsterdam.

Reesink, G.P., 1993. "Inner speech" in Papuan languages. Language and Linguistics in Melanesia 24, 217225.

Reesink, G.P., 1999. A Grammar of Hatam, Bird's Head Peninsula, Irian Jaya. Pacific Linguistics, Canberra.

Rennison, J.R., 1997. Koromfe. Routledge, London and New York.

Rice, K., 1986. Some remarks on direct and indirect speech in Slave (Northern Athapaskan). In: Coulmas (1986), pp. $47-76$.

Rice, K., 1989. Slave. Mouton de Gruyter, Berlin.

Romaine, Suzanne, Lange, Deborah, 1998. The use of like as a marker of reported speech and thought: a case of grammaticalization in progress. In: Cheshire, Jenny, Trudgill, Peter (Eds.), Gender and Discourse. In: The Sociolinguistics Reader, vol. 2. Arnold, London, pp. 240-277.

Rumsey, A., 1982. An Intra-Sentence Grammar of Ungarinjin, North-Western Australia. Pacific Linguistics, Canberra.

Rumsey, A., 1990. Wording, meaning and linguistic ideology. American Anthropologist 92, 346-361.

Sakita, T.I., 2002. Discourse perspectives on tense choice in spoken-English reporting discourse. In: Güldemann and von Roncador (2002), pp. 173-198.

Saxton, L., 1998. Complement clauses in Dogrib. In: Hinton, Leanne, Munro, Pamela (Eds.), Studies in American Indian Languages. Description and Theory. University of California Press, Berkeley, pp. 204-211.

Schaub, W., 1985. Babungo. Routledge, London.

Schauber, E., 1979. The syntax and semantics of questions in Navajo. Garland, New York.

Sohn, Ho-min, 1994. Korean. Routledge, London and New York.

Sulkala, H., Karjalainen, M., 1992. Finnish. Routledge, London and New York.

Tamura, S., 2000. The Ainu Language. Sanseido, Tokyo.

Taylor, C., 1985. Nkore-Kiga. Croom Helm, London.

ten Cate, A.P., 1996. Modality of verb forms in German reported speech. In: Janssen and van der Wurff, 1996a, pp. 189-211. 
Tida, Syuntarô, 2006. A grammar of the Dom language, a Papuan language of Papua New Guinea. Ph.D. dissertation, University of Kyoto.

Travis, C., 2006. Dizque: a Colombian evidentiality strategy. Linguistics 44, 1269-1298.

Van Der Mark, Sheena, 2007. A grammar of Vinitiri. Ph.D. dissertation, La Trobe University.

van der Voort, H., 2000. A grammar of Kwaza. Ph.D. dissertation, University of Leiden.

van Enk, G.J., de Vries, L.J., 1997. The Korowai of Irian Jaya. Their Language in its Cultural Context. Oxford University Press, New York.

Vlasto, A.P., 1986. A Linguistic History of Russia to the End of the Eighteenth Century. Clarendon Press, Oxford.

de Vries, L.J., 1990. Some remarks on direct quotation in Kombai. In: Pinkster, H., Genee, I. (Eds.), Unity in Diversity: Papers presented to Simon C. Dik on his 50th birthday. Foris, Dordrecht, pp. 291-309.

Wierzbicka, A., 1974. The semantics of direct and indirect discourse. Papers in Linguistics 7, $267-307$.

Wiesemann, U., 1990. A model for the study of reported speech in African languages. Journal of West African Languages XX (2), 75-80.

Zuckermann, Ghil'ad, 2006. Direct and indirect speech in straight-talking Israeli. Acta Linguistica Hungarica 53, $467-481$. 